\title{
Integrating and ranking sustainability criteria for housing
}

\section{ABSTRACT}

Numerous researchers have determined sustainability criteria relating to environmental performance but the other two sustainability components - economic and social performance - have not been taken into consideration in an integrated and hierarchy manner. Existing sustainability assessment methods (e.g., LEED, GBI, IGBC, and BREEAM) ignore the economic and social aspects, and sustainable criteria are not prioritized for decision making facilitation. To prioritize sustainable criteria for residential buildings in the triquetrous sustainability model including environmental, economic, and social in a global and integrated manner, a Fuzzy-AHP tool was employed and a structured expert-based development process comprised of seventeen building practitioners and eight academics from sixteen nations was conducted globally among carefully selected experts. A Fuzzy Weighted Hierarchy for Triquetrous Sustainability (FWH-TS) in residential buildings was developed at the end of this study. Assisted by programmers, the FWH-TS is expected to be developed into a PC software or Apps in the near future to improve construction management.

Keywords: Fuzzy-AHP, Fuzzy Weighted Hierarchy, Triquetrous Sustainability, Residential Building, Sustainable Environmental System

\subsection{INTRODUCTION}

The notion of sustainability was realized by early human beings (Khalid et al., 2013) with our hunter-gatherer ancestors perceiving the essence of ensuring resources remain available through sustainable principles in a manner that was long forgotten until the last century (Hill \& Bowen, 1997). The chance for reviving of sustainability concept appeared at the time when a new perception which labeled as 'sustainable development' was presented in 1987 in Brundtland's Report (Abidin, 2009). Afterwards, many industries focused on sustainability practices and the building industry was not an exception (Lau, 2013). Sustainability has emerged as an increasingly important principle in construction due to the considerable industrial effects on both the environmental and society (Myers, 2005). The notion of sustainability in construction has primarily focused on the restricted resources, particularly energy and the reduction of the impact on the natural surroundings with the consideration of technical concerns such as materials and construction technologies (Amran et al., 2013). The recognition of non-technical concerns has become popular in terms of social and 
economic sustainability in the 21st Century (Lawanson \& Fadare, 2013). Globally, many regions are now witnessing a steady process of industrialization and urbanization, leading to an significant volume of construction work performed in the developmental phases (Dassen et al., 2013). In order to enhance the sustainable development of the economics and society alongside environmental sustainability, it is crucial to establish an effective sustainability hierarchy addressing all of the triquetrous criteria of environmental, economic, and social aspects (Manan et al., 2010).

Numerous researchers have determined the sustainability criteria for environmental performance but the other two components in sustainability including economic and social performances have not been taken into consideration in an integrated and hierarchy manner. Most of the existing sustainability assessment methods (e.g., LEED, GBI, IGBC, and BREEAM) consider only the environmental aspects and ignore the economic and social aspects and sustainable criteria which are therefore not prioritized to facilitate decision making (Zhang et al., 2006). Extending concepts pioneered by IGB and LEED to infrastructure (but which may apply equally well to residential, commercial, and institutional buildings), the Envision Rating System developed in 2010 by the Institute for Sustainable Infrastructure includes environmental and societal factors amongst the five categories that are evaluated: 1) quality of life, 2) leadership, 3) resource allocation, 4) natural world, and 5) climate and risk. While these assessment methods may incorporate some environmental considerations, they sometimes ignore societal aspects. Most importantly, these frameworks provide insufficient guidance on how to simultaneously evaluate and balance the tensions between the triple concerns.

Multi-Criteria Decision Making (MCDM) techniques are gaining recognition as supporting sustainable solutions and a number of methods derived from weighted averages, outranking, priority setting, and fuzzy principles are being used for sustainable decisions. Analytical Hierarchy Process (AHP) is a commonly employed MCDM technique based on the principle of decomposing complicated problems into a hierarchy with goal on the top, criterions and sub-criterions at levels and sub-levels, and decision options at the bottom of the hierarchy (Pohekar \& Ramachandran, 2004). In order to make a decision, the most creative task is to choose the crucial criteria (Saaty, 2008). However, as there are numerous sustainable criteria in triquetrous sustainability, decision-making over these three groups is complicated and the prioritization of sustainability criteria could facilitate improved decision-making. The goal of this research is to determine and prioritize sustainable performance criteria for residential buildings in the triquetrous sustainability model including 
environmental, economic, and social factors in a global and integrated manner. A Fuzzy Weighted Hierarchy for Triquetrous Sustainability (FWH-TS) in residential buildings was developed at the end of this study. In terms of theoretical contribution, this study fills the gap by providing a fuzzy weighted triquetrous sustainability model. In terms of practice, the developed FWH-TS is able to assist construction practitioners including developers, contractors, and consultants in making decisions to allot optimum budget and resources based on the priority weight of each sustainable criterion over the entire lifecycle for a residential building.

\subsection{TRIQUETROUS SUSTAINABLE CRITERIA FOR RESIDENTIAL BUILDINGS}

The notable growth of sustainable development is undoubtedly a valuable transition in the evolving relationship between humans, nature, and groups of people (Hopwood et al., 2005). Sustainable development is defined by Ortiz et al. (2009) as improving the quality of life, and therefore enabling individuals to reside in healthy surroundings and enriching the social, economic, and environmental conditions for both the present and future generations (Ortiz et al., 2009). Efforts have been made to define sustainable development. However, most focus on only a few common elements; e.g., the environment, quality of life, and future generations. In Brundtland's (1987) report, sustainable development is development that meets the needs of the present without compromising the ability of future generations to meet their own needs. This definition is favored since it contains the opportunity for adjusting people's needs with the bio-physical environmental management goals by means of economic development (Vallance et al., 2011). Sustainable development consists of fine-tuning the quality of life experienced while examining the needs of fellow citizens and future generations (Lützkendorf \& Lorenz, 2005). The construction industry is among the primary exploiters of natural resources, both mineral and biological; therefore, actions by the construction industry bring about irreversible changes in the natural environment and increase atmospheric emissions (Spence \& Mulligan, 1995). As a result of present worldwide population growth trends, this predicament is anticipated to rapidly become worse (Dixit et al., 2010). Therefore, the necessity of sustainable approach for the construction initiatives is clear in order to protect the environment, develop the economy, and support the society, providing the foundation for triquetrous sustainability.

Traditional residential building design has mainly concentrated on the technical feasibility along with the financial viability of the capital investment. However, the conversion to sustainable structures and urban communities ought to satisfy the complications posed by a variety of further 
environmental, social, and economic concerns; e.g., growing energy charges, resource exhaustion, and new regulatory requirements (Georgiadou et al., 2012). Although the conventional design and the construction initiatives concentrate on cost, performance, and quality elements, sustainable design and construction offers the challenges of reducing both resource consumption and environmental degradation along with establishing a healthier built environment and making sure individual health and comfort (Sev, 2009). There is no existing comprehensive framework including all three aspects of sustainability within the building lifecycle. In order to establish such a comprehensive hierarchy for residential buildings, appropriate sustainable criteria have been selected from various publications together with industry guidelines; e.g., LEED (2002), GBI (2010), IGBC Green Homes (2009), DGNB (2009).

\subsection{Environmental criteria for sustainability}

The environmental criteria includes six groups, viz.: a) sustainable site considerations; b) water efficiency considerations; c) energy and atmosphere considerations; d) materials and resources considerations; e) indoor environmental quality; and, f) innovation and design process considerations. Each criterion subsumes a range of detailed sub-criteria, discussed in the following paragraphs. The criteria are based on prior criteria from related frameworks (e.g., LEED and IGBC) and focus solely on the immediate surroundings of the construction site (i.e., they exclude wider implications such as load on public utilities such as drinking water or sewage systems resulting from the construction). The researchers compiled appropriate criteria based on their expertise and the other frameworks, eliminated overlapping criteria where they essentially measured the same concepts, and ensure criteria addressed reduced waste (in environmental efficiency) or appropriate societal measures.

\section{a) Sustainable Site Considerations}

The criterion for sustainable site considerations criterion consists of four sub-criteria, viz. a1) land sensitivity considerations; a2) pollution reduction considerations; a3) considerations to develop damaged areas; and, a4) ecosystem preservation. Land sensitivity focuses on preventing - wherever possible - the unrecoverable impacts on the natural environment from executing a project. Managing erosion to decrease harmful effects on water and air quality is extremely important. In addition, developments should be patterned after other urban locations with respect to enhancing available infrastructure, preservation of green fields, and the maintenance of habitats and natural resources. 
Land sensitivity considerations also include preservation of the natural topography of the site to prevent later disturbance to the site. According to this criterion, earthwork and excavation should be reduced during structural operations (GBI, 2010; IGBC Green Homes, 2009; LEED, 2002; Shen et al., 2007).

The second sub-criterion is pollution reduction considerations, which relates to efficient land use and actions taken to prevent land-based pollution. Possible air, water, light and noise pollution from the suggested project and the effects on the local climate should be investigated (Kim et al., 2005; LEED, 2002; Shen et al., 2007).

The third sub-criterion is the consideration for developing damaged areas, which deals with re-establishment of damaged and affected areas to produce habitats and to increase biodiversity. Rehabilitation of affected sites wherein development is challenging by actual or even recognized environmental pollution is crucial in order to lower the burden on untouched land (Lützkendorf \& Lorenz, 2005).

The fourth sub-criterion is ecosystem preservation within which possible ecological risks and positive aspects connected with the suggested project should be investigated. A reduction of heat islands in order to diminish the effect on the microclimate and both human and wildlife habitats must be accounted for. In addition, preserving and developing green areas is a part of ecosystem preservation (IGBC Green Homes, 2009; LEED, 2002).

\section{b) Water Efficiency Considerations}

The water efficiency considerations are divided into three sub-criteria: b1) reduction of potable water consumption; b2) reduction of loss and waste; and, b3) implementation of alternative resources. The first sub-criterion is the reduction of potable water consumption, which deals with minimizing or eradicating the utilization of potable water for the landscaping and irrigation purposes, and the reduction of water consumption by maximizing water efficient fittings, water recycling, and water metering (GBI, 2010; LEED, 2002).

The second sub-criterion is the reduction of the loss and waste, to minimize the amount of water loss and waste by implementing treated grey water for flushing requirements, irrigation, landscaping, and 
innovative wastewater technologies (IGBC Green Homes, 2009). The third sub-criterion is implementation of alternative resources, which focuses on making available rainwater harvesting systems in order to trap the roof water produced from the roof area. This is then exploited to support landscape irrigation or indoor water use (LEED, 2002).

\section{c) Energy and Atmosphere Considerations}

Energy and atmosphere considerations can be divided into four main sub-criteria: c1) commissioning of building systems; c2) energy performance considerations; c3) reduction of non-renewable energy use; and, c4) ozone protection considerations. The first sub-criterion is commissioning of building systems that concentrates on checking and ensuring essential building elements are calibrated and function as expected (LEED, 2002).

The second sub-criterion is energy performance considerations, relating to developing the best possible level of energy efficiency for the base building and systems. Afterwards, trying to attain increasing levels of energy performance above the required standard to reduce environmental effects related to significant energy use. In addition, encouraging improvement of thermally comfortable environments to minimize air-conditioning use in residential buildings, leading to reduced $\mathrm{CO} 2$ emissions, is vital as an energy performance consideration. Application of high efficiency lighting systems should be supported with the intention to lessen energy intake (GBI, 2010; LEED, 2002).

Within the third sub-criterion, reduction of non-renewable energy, the emphasis is on the significant environmental effects linked to fossil fuel energy use by promoting on-site renewable energy self-supply development (Shen et al., 2007). The fourth sub-category is ozone protection considerations through preventing the use of particular refrigerants and ozone layer depleting gases (IGBC Green Homes, 2009).

d) Materials and Resources Considerations

This criterion is categorized into four sub-criteria: d1) waste management; d2) resource depletion considerations; d3) materials' properties; and, d4) implementation of regional materials. The first sub-criterion focuses on waste reduction program evaluation and discussion at site progress meetings. To escalate the amount recycling, materials ought to be accumulated separately as a way to 
prevent mixing diverse waste materials. Reducing on-site waste by using off-site fabrication is crucial (Asif et al., 2007; IGBC Green Homes, 2009; LEED, 2002).

Resource depletion considerations focuses on the reuse of building materials and restricting the call for virgin materials. Implementing building products that entail recycled content materials should be escalated to minimize effects associated with extraction and processing of new virgin materials. In addition, the reduced use of and therefore depletion of both limited raw materials and long-cycle renewable materials by substituting them with instantly renewable materials is crucial (Ding, 2005; Shen et al., 2007).

Materials' properties focuses on key attributes of materials; e.g., degree of processing required, maintainability, resistance to potential damage or decay, and technical performance (LEED, 2002; Pearce et al., 2012). The fourth sub-criteria is implementation of regional materials which focuses on increasing desires for building materials and products that are extracted and manufactured within the region, which both contributes to the regional economy and reduces environmental effects from transportation (Pearce et al., 2012).

e) Indoor Environmental Quality

Indoor environmental quality criterion is divided into four sub-criteria: e1) thermal comfort; e2) indoor air quality; e3) visual comfort; and, e4) aural comfort. The first sub-criterion is to assist construction designers to create an indoor climate in which building occupants feel thermally comfortable (Lai et al., 2009; Nicol \& Humphreys, 2002).

Indoor air quality emphasizes ventilation effectiveness, construction IAQ management plan, environmental Tobacco smoke (ETS) control, monitoring and reduction of CO2 emissions, indoor chemicals, and pollutant source control. Controllability of systems (thermal, ventilation and lighting systems) by occupants should be implemented to ensure high quality indoor air for occupants (Lützkendorf \& Lorenz, 2005).

Visual comfort focuses on optimizing and balancing both visual comfort and low energy consumption (Ochoa et al., 2012). The fourth sub-criterion, aural comfort, focuses on ensuring that building walls and floor systems are designed with sufficient sound absorption capability to sustain 
This is a copy of the "Post-print" (i.e., the authors' final draft, post-refereeing). Published as:

Abdul-Rahman, H., Wang, C., Wood, L. C., \& Ebrahimi, M. (in press). Integrating and ranking sustainability criteria for housing. Engineering Sustainability.

suitable acoustical quality for occupants and neighbors (Kim, et al., 2005; Lai et al., 2009; Wang et al., in press).

f) Innovation and Design process Considerations

The last environmental criterion is innovation and design process considerations: f1) innovation in design and f2) environmental design. Innovation in design offers design teams and project participants the opportunity to be awarded for performance above minimum requirements (Holden \& Scerri, 2013). Georgiadou (2012) claims eco-innovation does not necessarily mean expensive solutions, but rather ones that are technically robust, socially responsible, and financially viable. Environmental design will be satisfied if knowledgeable designers are selected. Important criteria to reach high quality environmental design include life-cycle design, environmentally conscious design, and modular and standardized design (Shen et al., 2007). Environmental criteria and sub-criteria for sustainability are summarized in Table 1.

Table 1: Environmental Criteria for Sustainability

\begin{tabular}{|c|c|c|c|}
\hline Level 1 & Level2 & Level 3 & Authors \\
\hline & & $\begin{array}{l}\text { 1.1.1. Land sensitivity } \\
\text { considerations }\end{array}$ & $\begin{array}{l}\text { (LEED, 2002), } \\
\text { (IGBC Green Homes, 2009) }\end{array}$ \\
\hline & 11 Suctainable Sites & $\begin{array}{l}\text { 1.1.2. Pollution Reduction } \\
\text { Considerations }\end{array}$ & $\begin{array}{l}\text { (Kim et al., 2005), } \\
\text { (LEED, 2002), } \\
\text { (Shen et al., 2007) }\end{array}$ \\
\hline & Considerations & $\begin{array}{l}\text { 1.1.3. Developing Damaged } \\
\text { Areas }\end{array}$ & $\begin{array}{l}\text { (GBI, 2010), } \\
\text { (Shen et al., 2007), } \\
\text { (Lützkendorf \& Lorenz, 2005) }\end{array}$ \\
\hline & & $\begin{array}{l}\text { 1.1.4. Ecosystem } \\
\text { Preservation }\end{array}$ & $\begin{array}{l}\text { (Shen et al., 2007), } \\
\text { (Kim et al., 2005), } \\
\text { (LEED, 2002), } \\
\text { (GBI, 2010), } \\
\text { (IGBC Green Homes, 2009) }\end{array}$ \\
\hline \multirow{5}{*}{$\begin{array}{l}\text { Environmental } \\
\text { sustainability }\end{array}$} & \multirow{2}{*}{$\begin{array}{l}\text { 1.2. Water Efficiency } \\
\text { Considerations }\end{array}$} & $\begin{array}{l}\text { 1.2.1. Reduction of potable } \\
\text { water consumption }\end{array}$ & $\begin{array}{l}\text { (LEED, 2002), } \\
\text { (GBI, 2010), } \\
\text { (IGBC Green Homes, 2009) }\end{array}$ \\
\hline & & $\begin{array}{l}\text { 1.2.3. Implementation of } \\
\text { alternative resources }\end{array}$ & $\begin{array}{l}\text { (LEED, 2002), } \\
\text { (GBI, 2010), } \\
\text { (IGBC Green Homes, 2009) }\end{array}$ \\
\hline & \multirow{3}{*}{$\begin{array}{l}\text { 1.3. Energy and } \\
\text { Atmosphere Considerations }\end{array}$} & $\begin{array}{l}\text { 1.3.1. Commissioning of } \\
\text { building systems }\end{array}$ & (LEED, 2002) \\
\hline & & $\begin{array}{l}\text { 1.3.2. Energy performance } \\
\text { considerations }\end{array}$ & $\begin{array}{l}\text { (LEED, 2002), } \\
\text { (GBI, 2010), } \\
\text { (IGBC Green Homes, 2009) }\end{array}$ \\
\hline & & $\begin{array}{l}\text { 1.3.3. Reduction of } \\
\text { non-renewable energy }\end{array}$ & $\begin{array}{l}\text { (LEED, 2002), } \\
\text { (GBI, 2010), } \\
\text { (IGBC Green Homes, 2009), } \\
\text { (Shen et al., 2007) }\end{array}$ \\
\hline
\end{tabular}


This is a copy of the "Post-print" (i.e., the authors' final draft, post-refereeing). Published as:

Abdul-Rahman, H., Wang, C., Wood, L. C., \& Ebrahimi, M. (in press). Integrating and ranking sustainability criteria for housing. Engineering Sustainability.

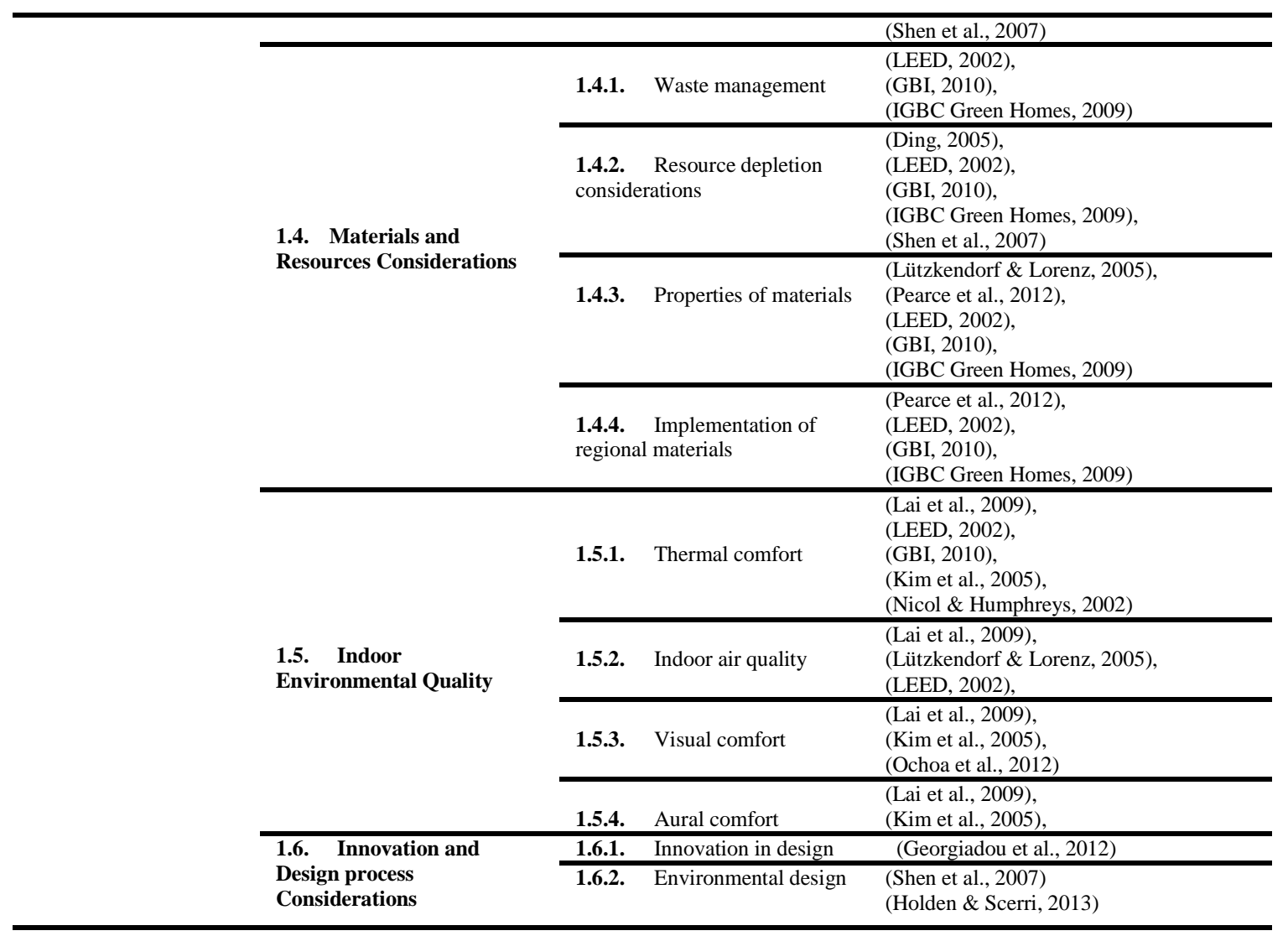

\subsection{Social criteria for sustainability}

Social sustainability criteria are classified into six major sub-criteria: a) Site and Equipment Considerations; b) Health and Comfort considerations; c) Job Opportunities; d) Safety Issues; e) Stakeholders’ Relationship; and, f) Architectural Issues.

a) Site and Equipment Considerations

Site and equipment considerations include five sub-criteria: a1) quality of infrastructure; a2) security of the site; a3) quality of facilities; a4) barrier-free built environment considerations; and, a5) land use considerations. Quality of infrastructure addresses factors including access to public transportation, quality of leisure and recreation infrastructure, improvement of infrastructure, and infrastructure burden during construction; i.e., the additional demand for water, road, energy, services, and space (Ceron-Palma et al., 2013).

Security of the site emphasizes protection of entry points, monitoring devices, and natural access control which can be helpful to providing security for residents (Buys et al., 2005). The third 
sub-criterion is quality of facilities which defined by Shen et al. (2007) as provision of community amenities for the harmonization of new settlements and local communities. The fourth sub-criterion is barrier-free built environment considerations that relate to access for physically disabled persons and protection against slipping and stumbling by all persons (Maria \& Stella, 2006). The final sub-criterion is land use considerations, focusing on the land choice for project site in a way that preserves cropland and natural resources. Provision of property at the end of project demolition to allow the development of new projects in accordance with the requirements of local community is also important (Shen et al., 2010).

b) Health and Comfort Considerations

Health and comfort considerations criterion are categorized into six major sub-criteria: b1) thermal comfort; b2) visual comfort; b3) acoustical comfort; b4) indoor air quality; b5) daylight and exposure to sunlight; and, b6) indoor hygiene. Assessment must be made of thermal comfort, operative temperature, asymmetry of radiation temperature and flooring temperature, humidity, and vertical thermal gradient (Ceron-Palma et al., 2013).

Visual comfort can be attained by well-balanced illumination without interferences (e.g., direct and reflected glare), adequate lighting levels, and the possibility to alter illumination to meet specific requirements (DGNB, 2009).

The third sub-criterion of acoustical comfort is focused on attaining low levels of disturbance and background noise (Mötzl \& Fellner, 2011). Indoor air quality criterion includes prevention of an increase in large particulate concentration within a home; e.g., indoor tobacco smoking, operation of gas stoves for cooking, and VOC pollutants (Lee et al., 2002; Sahely et al., 2005; Zavrl et al., 2009). The fifth is daylight and exposure to sunlight. Appropriate use of sunlight within buildings improves the staff productivity and reduces sick time. Sunlight has several advantages: it can enhance the quality of light in a space and decreases the amount of electrical lighting needed. More importantly, sunlight offers huge psychological advantages to building users; this may be a primary purpose for enhancing the use of sunlight rather than simply cutting back on electrical lighting demands (Maria \& Stella, 2006). The sixth sub-criterion of this group is indoor hygiene, the main concern of which is to eliminate adverse effects on users' health conditions. Indoor hygiene also includes sub-criteria; e.g., refuse disposal, water supply, pest control, and cleaning (DGNB, 2009). 
c) Job Opportunities

Job opportunities is divided into two:c1) direct employment and c2) indirect employment. Construction laborers, specialists, and engineers are included in local labor market (Shen et al., 2007). Indirect employment is defined by Shen et al. (2007) as employment generated by the up-and-down-stream industries and services to construction.

d) Safety Issues

Safety issues include d1) design considerations towards safety and d2) management considerations towards safety. Design considerations towards safety includes architectural features (e.g., height and disposition, means of escape, means of access, and amenities), building services (e.g., fire service installations, electrical installations, and fuel supply), and the external environment (e.g., proximity to special hazards and proximity to fire station) (Ho et al., 2008). Management considerations towards safety includes operations and maintenance issues (e.g., structural condition, building services condition, exit routes condition, and fire compartmentation) and management approaches (e.g., owners' duties, documentation, emergency preparedness, and financial arrangements) (Ho et al., 2008).

e) Stakeholders’ Relationship

The stakeholders' relationship criterion is classified as either e1) communication to the public or e2) public participation. Communication to the public emphasizes increasing public awareness about the project and possible effects on the public of project demolition (Shen et al., 2007). Public participation aims to generate improved decisions around multiple challenges regarding risks to well-being, health, and the environment (Sharifi \& Murayama, 2013; Kasemir, 2003; Sahely et al., 2005).

f) Architectural Issues

Architectural issues include either f1) architectural heritage considerations or f2) architectural functionality and flexibility considerations. Architectural heritage considerations focus on prevention 
This is a copy of the "Post-print" (i.e., the authors' final draft, post-refereeing). Published as:

Abdul-Rahman, H., Wang, C., Wood, L. C., \& Ebrahimi, M. (in press). Integrating and ranking sustainability criteria for housing. Engineering Sustainability.

of negative impact of project development on any kind of cultural heritage (Ding, 2005). Furthermore, buildings should provide proper functionality to residents and be able to be altered based on residents' needs (Zavrl et al., 2009). The criteria and sub-criteria in social sustainability are summarized in Table 2.

Table 2: Social Criteria and Sub-Criteria in Sustainability

\begin{tabular}{|c|c|c|c|}
\hline Level 1 & Level2 & Level 3 & Author \\
\hline \multirow{19}{*}{ Social sustainability } & \multirow{5}{*}{$\begin{array}{l}\text { 1.1. Site and Equipment } \\
\text { Considerations }\end{array}$} & 1.1.1. Quality of Infrastructure & $\begin{array}{l}\text { (Newell et al., 2013), } \\
\text { (Shen et al., 2007), } \\
\text { (Ceron-Palma et al., 2013) }\end{array}$ \\
\hline & & 1.1.2. Security of the Site & $\begin{array}{l}\text { (Buys et al., 2005), } \\
\text { (Maria \& Stella, 2006) } \\
\end{array}$ \\
\hline & & 1.1.3. Quality of Facilities & $\begin{array}{l}\text { (Ceron-Palma et al., 2013), } \\
\text { (Maria \& Stella, 2006), }\end{array}$ \\
\hline & & 1.1.4. Barrier-free Built Environment considerations & (Maria \& Stella, 2006), \\
\hline & & 1.1.5. Land use considerations & (Shen et al., 2010) \\
\hline & \multirow{6}{*}{$\begin{array}{l}\text { 1.2. Health and Comfort } \\
\text { considerations }\end{array}$} & 1.2.1. Thermal Comfort & $\begin{array}{l}\text { (Ceron-Palma et al., 2013), } \\
\text { (DGNB, 2009) }\end{array}$ \\
\hline & & 1.2.2. Visual Comfort & (DGNB, 2009) \\
\hline & & 1.2.3. Acoustical Comfort & $\begin{array}{l}\text { (Mötzl \& Fellner, 2011), } \\
\text { (DGNB, 2009) }\end{array}$ \\
\hline & & 1.2.4. Indoor Air Quality & (Lee et al., 2002) \\
\hline & & 1.2.5. Daylight and Exposure to Sunlight & (Shen, et al., 2007) \\
\hline & & 1.2.6. Indoor Hygiene & (DGNB, 2009) \\
\hline & \multirow{2}{*}{ 1.3. Job Opportunities } & 1.3.1. Direct Employment & (Shen, et al., 2007) \\
\hline & & 1.3.2. Indirect Employment & (Shen, et al., 2010) \\
\hline & \multirow{2}{*}{ 1.4. Safety Issues } & 1.4.1. Design Considerations towards safety & (Ho et al., 2008) \\
\hline & & 1.4.2. Management considerations towards safety & (Ho et al., 2008) \\
\hline & \multirow[b]{2}{*}{$\begin{array}{l}\text { 1.5. Stakeholders' } \\
\text { Relationship }\end{array}$} & 1.4.3. Communication to the Public & (Shen et al., 2007) \\
\hline & & 1.4.4. Public Participation & $\begin{array}{l}\text { (Sahely et al., 2005), } \\
\text { (Kasemir, 2003), } \\
\text { (Sharifi \& Murayama, 2013) }\end{array}$ \\
\hline & \multirow[b]{2}{*}{ 1.6. Architectural Issues } & 1.6.1. Architectural heritage considerations & (Ding, 2005), \\
\hline & & $\begin{array}{l}\text { 1.4.5. Architectural Functionality and flexibility } \\
\text { considerations }\end{array}$ & (Zavrl et al., 2009) \\
\hline
\end{tabular}

\subsection{Economic criteria in sustainability}

Economic criteria for sustainability are classified into four major sub-criteria: a) Expenditure; b) Revenue; c) Investment in innovation, research and development; and, d) Improvement of local economic environment.

a) Expenditure

The expenditure criterion consists of a1) capital costs; a2) lifecycle costs; and, a3) environmental costs. Capital costs are the expenses relating to construction clients. Capital costs are the construction 
costs, associated legal and design fees, property acquisition, site preparation costs, VAT (Value Added Tax), and financing costs (Mohamed et al., 2002). Lifecycle costs are costs to owners and building users after the completion of projects; e.g., maintenance and facilities management costs, operational costs, and replacement and disposal costs (Quigley et al., 2007). Environmental costs are imposed on the community in the form of pollution; e.g., from the production of concrete, the use of harmful materials, and other impacts from construction such as traffic due to the location of the building (Quigley et al., 2007).

\section{b) Revenue}

The revenue criterion consists of: b1) value stability; b2) lifecycle profit; and, b3) distribution of project income. A building intended for sustainability could be effortlessly modified to altering needs. Changes in the use of the building can come about from tenant or user alterations or by reorganization of tenants. An excellent level of flexibility and adaptability of buildings under the aim of sustainability occurs in the event that the changes could be achieved with few resources (DGNB, 2009). Profit assessments ought not to be emphasized on stage or even sectional earnings and profits, but it should include total revenue and profit from operating a building project across its whole lifecycle (Shen et al., 2007). The final sub-criterion of this category is the distribution of project income defined by Shen et al. (2007) as reinvestment, dividends, and paybacks.

c) Investment in Innovation, Research and Development

This criterion include both $\mathrm{c} 1$ ) expenditure on $\mathrm{R} \& \mathrm{D}$ and $\mathrm{c} 2$ ) reserve funds. Expenditure on $\mathrm{R} \& \mathrm{D}$ indicates the amount of investment allocated to R\&D activities toward sustainability. In addition, sustainable construction companies need to ensure there are accessible reserve funds to support survival during sustainable development (Sahely et al., 2005).

d) Improvement of Local Economic Environment

This criterion is classified to four main sub-criteria: d1) local material choice; d2) utilization of local infrastructure; d3) improvement of local labor market; and, d4) improvement of local businesses. Choosing to use local materials for construction as much as possible is the main concern of the first sub-criterion. A project needs to assist local economy by taking advantage of the infrastructure in 
This is a copy of the "Post-print" (i.e., the authors' final draft, post-refereeing). Published as:

Abdul-Rahman, H., Wang, C., Wood, L. C., \& Ebrahimi, M. (in press). Integrating and ranking sustainability criteria for housing. Engineering Sustainability.

order to produce economic profits (Shen et al., 2010). Improvement of the local labor markets highlights the importance of recruiting a range of local laborers (e.g., construction workers, engineers, managers, and janitors) over the different stages of the building lifecycle. Local authorities should encourage the involvement of citizens, local institutions, and private companies and promote thinking globally but acting locally (Pulselli et al., 2006). Finally, consideration should be given to business opportunities for local suppliers, contractors, and consultants as this will improve economic development locally. The economic criteria for sustainability are summarized in Table 3.

Table3: Economic Criteria for Sustainability

\begin{tabular}{|c|c|c|c|}
\hline Level 1 & Level2 & Level 3 & Author \\
\hline \multirow{12}{*}{$\begin{array}{l}\text { Economic } \\
\text { sustainability }\end{array}$} & \multirow{3}{*}{ 1.1. Expenditure } & 1.1.1. Capital costs & $\begin{array}{l}\text { (Quigley et al., 2007), } \\
\text { (Mohamed et al., 2002) }\end{array}$ \\
\hline & & 1.1.2. Life-cycle costs & $\begin{array}{l}\text { (Quigley et al., 2007), } \\
\text { (Mohamed et al., 2002) }\end{array}$ \\
\hline & & 1.1.3. $\quad$ Environmental costs & (Quigley et al., 2007) \\
\hline & \multirow{3}{*}{ 1.2. Revenue } & 1.2.1. Value stability & (DGNB, 2009) \\
\hline & & 1.2.2. $\quad$ Life-cycle profit & (Shen et al., 2007) \\
\hline & & 1.2.3. Distribution of project income & (Shen et al., 2007) \\
\hline & \multirow{2}{*}{$\begin{array}{l}1.3 . \quad \text { Investment in } \\
\text { innovation, research and } \\
\text { development }\end{array}$} & 1.3.1. Expenditure on R \&D & (Sahely et al., 2005) \\
\hline & & 1.3.2. Reserve funds & (Sahely et al., 2005) \\
\hline & \multirow{4}{*}{$\begin{array}{l}\text { 1.4. Improvement of local } \\
\text { economic environment }\end{array}$} & 1.4.1. $\quad$ Local material choice & $\begin{array}{l}\text { (Shen et al., 2007), } \\
\text { (Shen et al., 2010) }\end{array}$ \\
\hline & & 1.4.2. Utilization of local infrastructure & $\begin{array}{l}\text { (Shen et al., 2007), } \\
\text { (Shen et al., 2010) }\end{array}$ \\
\hline & & 1.4.3. Improvement of local labor market & (Pulselli et al., 2006) \\
\hline & & 1.4.4. Improvement of local businesses & (Shen et al., 2007) \\
\hline
\end{tabular}

\subsection{FUZZY-AHP FOR DECISION MAKING}

Decision making is a crucial element in many different careers and daily life. Construction practitioners and scholars must give priority to some options and devote less attention to others. A well-known tool for prioritizing effective criteria and sub-criteria in the realm of decision making is Analytic Hierarchy Process (AHP).

Residential buildings are prone to many uncertainties and vagueness. The utilization of fuzzy reasoning techniques offers an effective tool to manage the doubts, uncertainties, and subjectivities associated with construction initiatives (Zeng et al., 2007). Promentilla et al. (2008) proposed the integration of fuzzy principles in a hierarchical network and asserted that human judgment declared in natural language is usually vague and uncertain, so using Fuzzy principles the vagueness can be limited significantly. The strength of AHP is that it can be simply integrated with other techniques. 
As a prioritizing tool, the judgment of experts plays a crucial role and is normally expressed in numerical scales. By applying fuzzy principles in comparison scale in AHP, the uncertainty in judgments can be controlled appropriately. In order to apply fuzzy principles in AHP, the fuzzy numbers should be considered rather than real numbers. Triangular fuzzy numbers are used for pairwise comparison scale of AHP in most of the studies. Fuzzy averaging is applied to aggregate the experts' opinions and judgments and the fuzzy average numbers will be transferred into crisp numbers. Afterwards, the eigenvector of the crisp matrix is calculated (Chang, 1996).

One stage of AHP relates to pairwise comparisons which should be conducted by experts and specialists. In this stage, experts give scores to paired criteria. However, due to nature of construction initiatives, experts will face difficulties in allocating absolute numbers to each of these criteria, making the relative comparison pragmatic. The approach can be further enhanced in AHP applications for construction activities by integrating Fuzzy set theory as this can better capture the vagueness of decision making. Therefore, instead of proposed point scale in AHP, language variables will be used which can be interpreted as fuzzy numbers is a great assistance. Fuzzy operations are applied to fuzzy numbers to further improve the results.

\subsection{RESEARCH METHODS AND PROCEDURES}

The aim of this research is to develop a Fuzzy Weighted Hierarchy for Triquetrous Sustainability (FWH-TS) for residential buildings. The research is principally a descriptive study assisted by quantitative approaches, to systematically explain a situation, issue, and phenomenon and explains attitudes regarding an issue. To prioritize categorized sustainable criteria, the AHP tool was selected and in the stage of pairwise comparison, where each set of two criteria were compared due to the relative weights of the criteria. Psychologists have demonstrated that it is less complicated and more precise to show your viewpoint on merely a couple of options compared to concurrently on almost all the choices using interview or questionnaire survey (Ishizaka \& Labib, 2011).

This study employed a structured interview approach among carefully selected industry experts. The questionnaire form developed for this structured interview consists of three sections addressing each of environmental, social, and economic criteria. A pilot survey was conducted to determine the contemplated criteria and to choose those specialists with related qualification and expertise to join the Fuzzy-AHP survey. 
As the goal of the research was to determine and prioritize performance criteria over a range of factors that may not be well-understood by laypeople or building residents, it was decided that the respondents that would be able to provide the most support for the research would be experts (either industry-based or academic). These individuals must have substantial experience with sustainability development in residential building projects. Their experience and immersion in the industry would allow them to understand contemporary practices and trends in the global construction industry. An initial list of experts was constructed based on personal contacts of the research group and by conducting an extensive internet-based search. The initial list was filtered by peer recommendation and published biographies. There were 64 building practitioners and 31 academic scholars were shortlisted and invited from 29 nations and regions. Finally, 17 building practitioners and eight academic scholars from 16 nations agreed and participated in the expert-based structured interview (participant profiles are presented in Table 4). These participating experts were interviewed by the research team using the same research instrument either in their office or through appointments when they attending international conferences during 2013. A pilot study was conducted to examine the relevance of the suggested criteria and to check the comprehensibility of terms. Some terms were unclear to all participants and so were changed, using feedback from the respondents involved in the pilot study. Finally, at any point, the respondents in the final interviews were able to clarify with the researchers the meaning of any term used during the process so that appropriate decisions were made.

The integrated Fuzzy-AHP tool was employed as a decision making approach for prioritizing relevant criteria and sub-criteria. Priority weights are achieved based on experts' judgment and selection. The application of fuzzy numbers for weighting scores instead of real numbers mitigates the associated fuzziness and uncertainty. The fuzzy rule was applied for averaging experts' judgments. After fuzzy averaging, defuzzification of fuzzy numbers was conducted to generate crisp numbers for determining priority weights. The following seven steps were conducted in this research.

Table 4: Demography of Experts

\begin{tabular}{|c|c|c|c|c|c|c|c|c|}
\hline Experts & Type & $\begin{array}{l}\text { Working } \\
\text { Country }\end{array}$ & Expertize & $\begin{array}{c}\text { Total } \\
\text { Working } \\
\text { Experience }\end{array}$ & $\begin{array}{c}\text { Experience in } \\
\text { Building } \\
\text { Sustainability }\end{array}$ & Position & Qualification & Gender \\
\hline $\mathrm{A}$ & Practitioner & UK & $\begin{array}{l}\text { Environmental } \\
\text { Sustainability }\end{array}$ & 27 & 23 & Senior Director & PHD & $\mathrm{M}$ \\
\hline B & Practitioner & UK & $\begin{array}{l}\text { Economic } \\
\text { Sustainability }\end{array}$ & 31 & 25 & Senior Director & Master & $\mathrm{M}$ \\
\hline $\mathrm{C}$ & Practitioner & Australia & Environmental & 24 & 24 & Project Director & Master & $\mathrm{M}$ \\
\hline
\end{tabular}


This is a copy of the "Post-print" (i.e., the authors' final draft, post-refereeing). Published as:

Abdul-Rahman, H., Wang, C., Wood, L. C., \& Ebrahimi, M. (in press). Integrating and ranking sustainability criteria for housing. Engineering Sustainability.

\begin{tabular}{|c|c|c|c|c|c|c|c|c|}
\hline & & & Sustainability & & & & & \\
\hline $\mathrm{D}$ & Academia & NZ & $\begin{array}{l}\text { Environmental } \\
\text { Sustainability }\end{array}$ & 29 & 21 & Professor & PHD & $\mathrm{M}$ \\
\hline $\mathrm{E}$ & Practitioner & US & $\begin{array}{l}\text { Economic } \\
\text { Sustainability }\end{array}$ & 32 & 13 & $\begin{array}{ll}\text { Senior } & \text { Project } \\
\text { Engineer } & \\
\end{array}$ & PHD & $\mathrm{M}$ \\
\hline $\mathrm{F}$ & Academia & NZ & $\begin{array}{l}\text { Social } \\
\text { Sustainability }\end{array}$ & 24 & 20 & Professor & PHD & $\mathrm{F}$ \\
\hline $\mathrm{G}$ & Academia & Australia & $\begin{array}{l}\text { Social } \\
\text { Sustainability }\end{array}$ & 18 & 17 & $\begin{array}{l}\text { Associate } \\
\text { Professor }\end{array}$ & PHD & $\mathrm{F}$ \\
\hline $\mathrm{H}$ & Practitioner & HK & $\begin{array}{l}\text { Economic } \\
\text { Sustainability }\end{array}$ & 22 & 14 & $\begin{array}{ll}\text { Senior } & \text { Project } \\
\text { Engineer } & \\
\end{array}$ & Master & $\mathrm{M}$ \\
\hline I & Practitioner & China & $\begin{array}{l}\text { Environmental } \\
\text { Sustainability }\end{array}$ & 26 & 25 & $\begin{array}{ll}\text { Senior } & \text { Project } \\
\text { Engineer } & \\
\end{array}$ & Bachelor & $\mathrm{M}$ \\
\hline $\mathrm{J}$ & Academia & Malaysia & Fuzzy-AHP & 33 & 11 & Professor & PHD & $\mathrm{F}$ \\
\hline $\mathrm{K}$ & Practitioner & Denmark & $\begin{array}{l}\text { Environmental } \\
\text { Sustainability }\end{array}$ & 23 & 19 & $\begin{array}{ll}\text { Senior } & \text { Project } \\
\text { Engineer } & \\
\end{array}$ & Master & $\mathrm{M}$ \\
\hline $\mathrm{L}$ & Academia & India & $\begin{array}{l}\text { Social } \\
\text { Sustainability }\end{array}$ & 34 & 17 & Professor & PHD & $\mathrm{F}$ \\
\hline $\mathrm{M}$ & Practitioner & Singapore & $\begin{array}{l}\text { Social } \\
\text { Sustainability }\end{array}$ & 27 & 20 & General Manager & Master & $\mathrm{M}$ \\
\hline $\mathrm{N}$ & Practitioner & Germany & $\begin{array}{l}\text { Environmental } \\
\text { Sustainability }\end{array}$ & 19 & 18 & $\begin{array}{ll}\text { Senior } & \text { Project } \\
\text { Engineer } & \\
\end{array}$ & Master & $\mathrm{M}$ \\
\hline $\mathrm{O}$ & Academia & Malaysia & $\begin{array}{l}\text { Social } \\
\text { Sustainability }\end{array}$ & 28 & 16 & Professor & PHD & $\mathrm{M}$ \\
\hline $\mathrm{P}$ & Practitioner & China & $\begin{array}{l}\text { Social } \\
\text { Sustainability }\end{array}$ & 30 & 22 & Senior Director & Master & $\mathrm{F}$ \\
\hline $\mathrm{Q}$ & Practitioner & Thailand & $\begin{array}{l}\text { Social } \\
\text { Sustainability }\end{array}$ & 26 & 19 & General Manager & Master & $\mathrm{M}$ \\
\hline $\mathrm{R}$ & Practitioner & Malaysia & $\begin{array}{l}\text { Environmental } \\
\text { Sustainability }\end{array}$ & 21 & 18 & Senior Director & Master & $\mathrm{M}$ \\
\hline $\mathrm{S}$ & Academia & HK & $\begin{array}{l}\text { Economic } \\
\text { Sustainability }\end{array}$ & 25 & 13 & Professor & PHD & $\mathrm{M}$ \\
\hline $\mathrm{T}$ & Practitioner & Japan & $\begin{array}{l}\text { Economic } \\
\text { Sustainability }\end{array}$ & 22 & 20 & Senior Director & PHD & $\mathrm{M}$ \\
\hline $\mathrm{U}$ & Practitioner & Iceland & $\begin{array}{l}\text { Environmental } \\
\text { Sustainability }\end{array}$ & 20 & 17 & $\begin{array}{ll}\text { Senior } & \text { Project } \\
\text { Engineer } & \\
\end{array}$ & Master & $\mathrm{F}$ \\
\hline $\mathrm{V}$ & Practitioner & Thailand & $\begin{array}{l}\text { Economic } \\
\text { Sustainability }\end{array}$ & 31 & 22 & General Manager & PHD & $\mathrm{M}$ \\
\hline $\mathrm{W}$ & Practitioner & Argentina & $\begin{array}{l}\text { Economic } \\
\text { Sustainability }\end{array}$ & 34 & 19 & General Manager & PHD & $\mathrm{M}$ \\
\hline $\mathrm{X}$ & Practitioner & Singapore & $\begin{array}{l}\text { Social } \\
\text { Sustainability }\end{array}$ & 27 & 16 & Senior Director & PHD & $\mathrm{F}$ \\
\hline $\mathrm{Y}$ & Academia & Netherlands & $\begin{array}{l}\text { Environmental } \\
\text { Sustainability }\end{array}$ & 22 & 14 & Professor & PHD & $\mathrm{M}$ \\
\hline
\end{tabular}

\section{Step 1: Establishment of hierarchy:}

In this step, the decision making problem was divided to relevant criteria, sub-criteria, and alternatives. The linear hierarchy entailing several elements were depicted and determined in this stage. The first level is the goal of the hierarchy. The second and third levels consist of criteria, sub-criteria, and the alternatives which decision should be made over. In order to determine priority weights of each criterion, relevant criteria and sub-criteria were categorized in three different categories (viz., environmental sustainability, social sustainability and economic sustainability) which formed a triquetrous sustainability. It needs the weights of each criterion or sub-criterion in comparison with all the rest of criteria and sub-criteria in three categories. Hence, by multiplying the weight of each criterion with the weight of relevant category, the exact weights were attained. In Figure 1 the environmental hierarchy was depicted. In the second level, six criteria of environmental sustainability are outlined. In the third level, the sub-criteria of each criterion are presented. Likewise, 
This is a copy of the "Post-print" (i.e., the authors' final draft, post-refereeing). Published as:

Abdul-Rahman, H., Wang, C., Wood, L. C., \& Ebrahimi, M. (in press). Integrating and ranking sustainability criteria for housing. Engineering Sustainability.

the social sustainable hierarchy and the economic sustainable hierarchy are presented in Figure 2 and Figure 3, respectively.

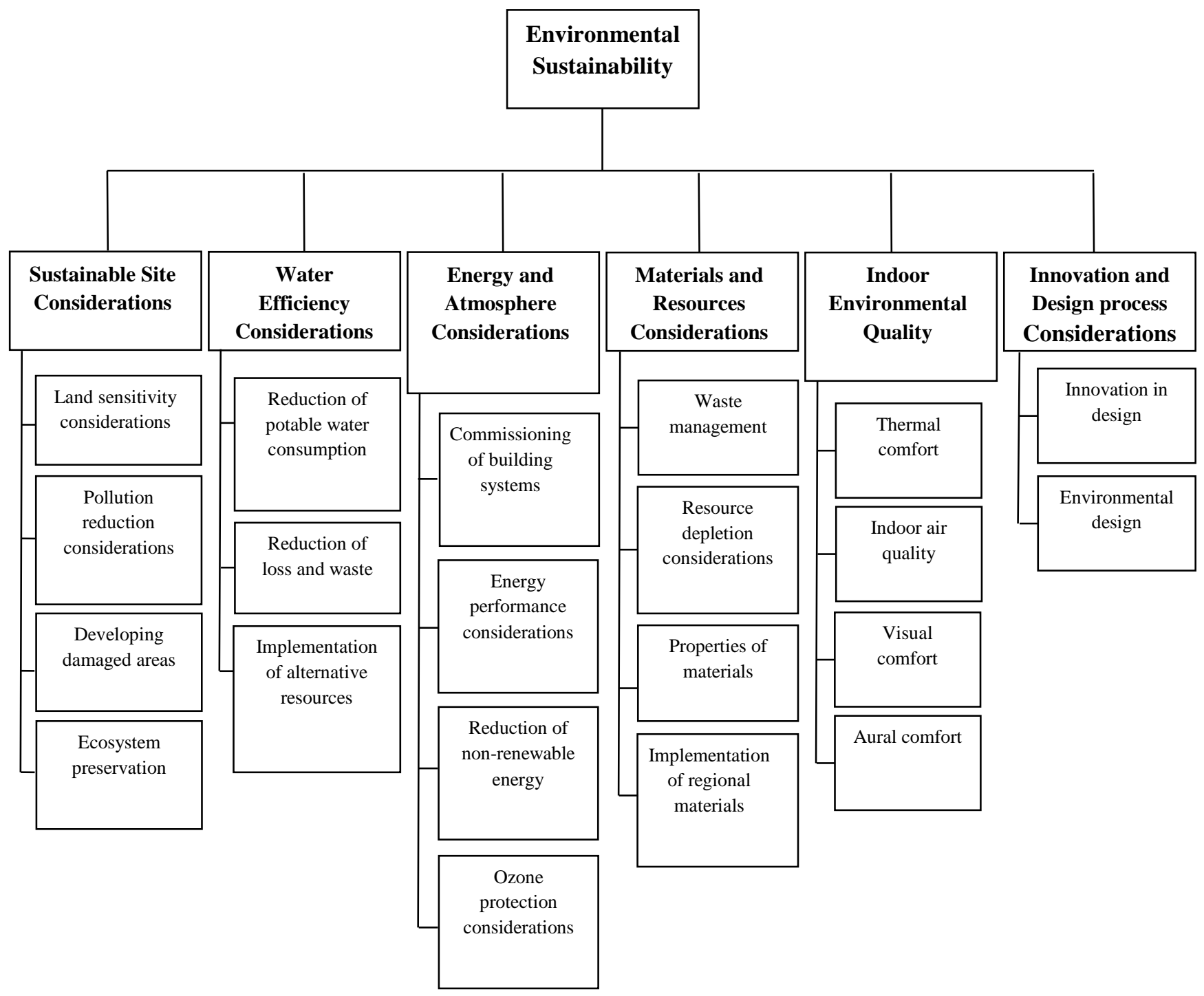

Figure 1: Environmental criteria for sustainability

\section{Step 2: Establishment of pairwise comparison matrices}

Step 2 in this study differs from the original AHP step in two ways. Firstly, there is no alternative in the setting of this study. Secondly, there are a greater number of indicators in this study than is usual. The dimension of each matrix is equal to $n(n-1) / 2$; since the number of indicators in this study is 52 , the dimensions of comparison matrix are as high as 1326 . Hence, a modification was made to the original AHP approach. Each block of factors was compared then the eigenvector of each group was 
This is a copy of the "Post-print" (i.e., the authors' final draft, post-refereeing). Published as:

Abdul-Rahman, H., Wang, C., Wood, L. C., \& Ebrahimi, M. (in press). Integrating and ranking sustainability criteria for housing. Engineering Sustainability.

calculated. By multiplying eigenvector of upper levels to lower levels the final weights of criteria were computed. In this step, the related pairwise comparison matrices were constructed based on the experts' judgment. Experts provided judgments on pairwise comparison toward sustainability criteria and were requested to give fuzzy scales when they were uncertain about the precise numerical values.

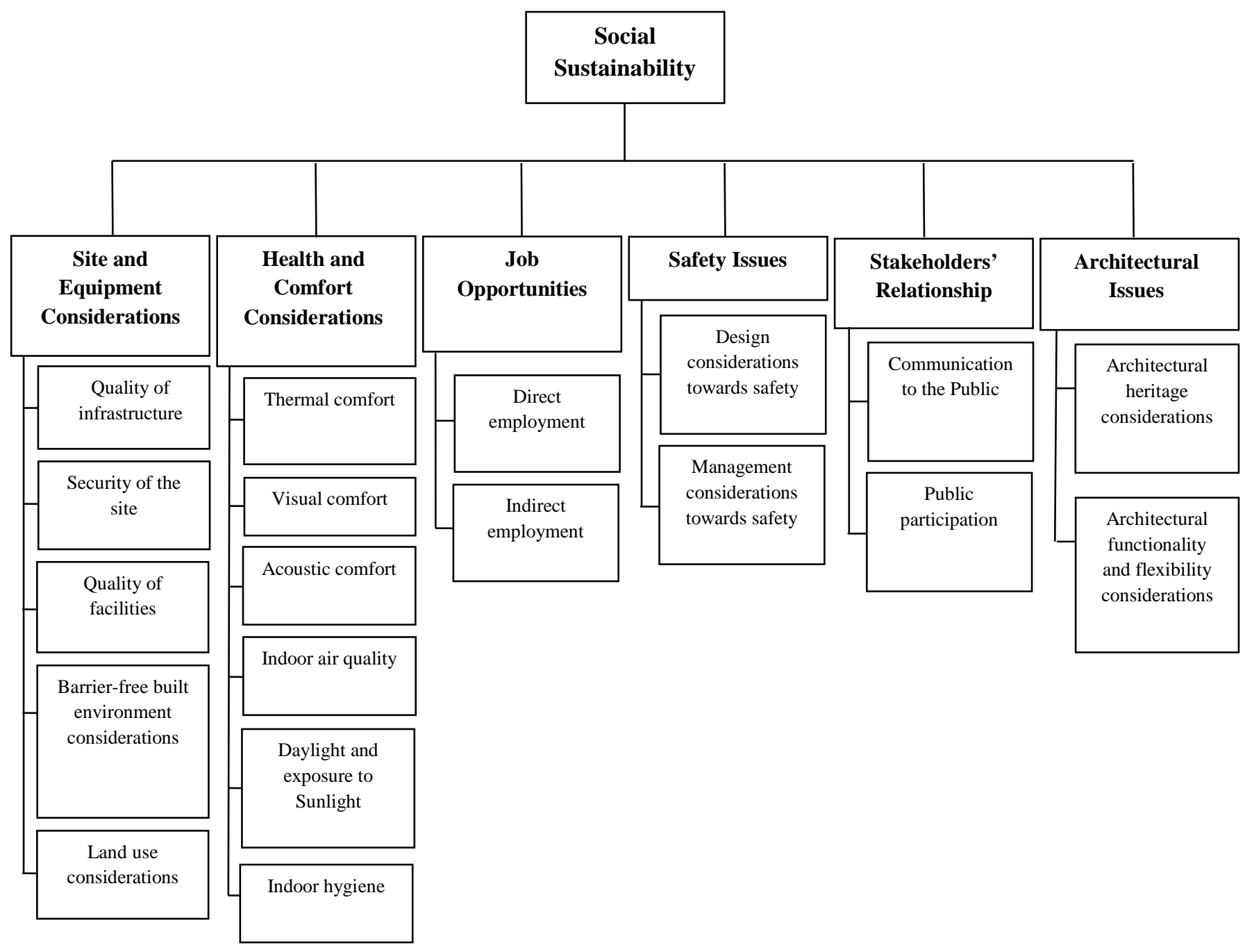

Figure 2: Social criteria for sustainability

\section{Step 3: Calculating the consistency ratio of questionnaires}

Each related consistency ratio in the comparison matrices was calculated for the four levels. Whenever the related consistency of a group was not acceptable, the expert was requested to redo the 
This is a copy of the "Post-print" (i.e., the authors' final draft, post-refereeing). Published as:

Abdul-Rahman, H., Wang, C., Wood, L. C., \& Ebrahimi, M. (in press). Integrating and ranking sustainability criteria for housing. Engineering Sustainability.

judgments for the same questions but in a purposely changed order to prevent prejudice. This process was repeated until all the consistency ratios became acceptable.

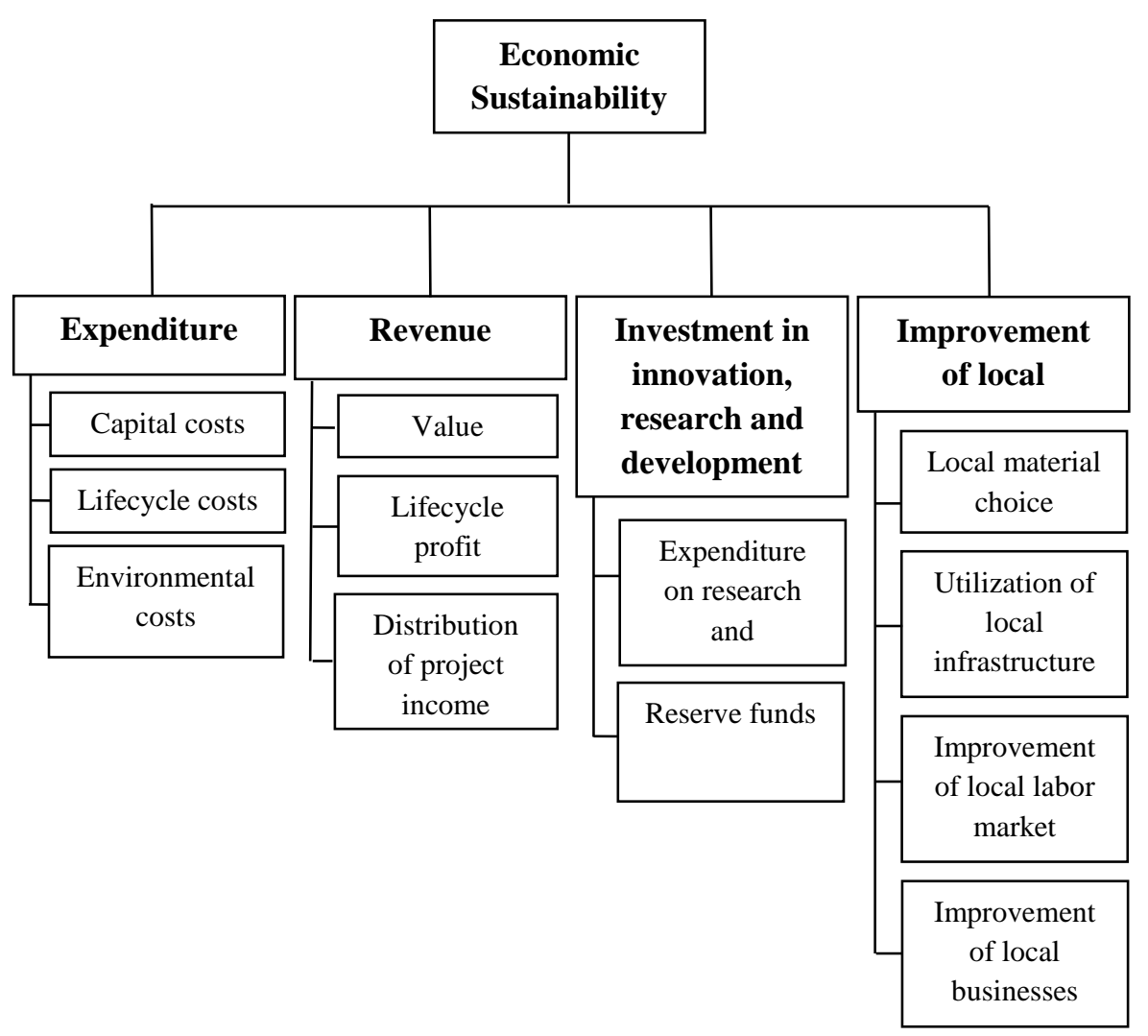

Figure 3: Economic criteria for sustainability

\section{Step 4: Converting linguistic judgment variables to fuzzy numbers}

Linguistic variables were converted to fuzzy numbers using Table 5. Triangular fuzzy numbers were utilized for pairwise comparison scale of AHP for the conversion of linguistic variables. Since in the comparison matrix in AHP all the elements were reversed with respect to the diagonal of matrix, the reverse of the fuzzy number was shown in the column named 'reciprocal scale'; these values represent the reverse of a number in fuzzy space.

Table 5: Fuzzy comparison scale (Tiryaki \& Ahlatcioglu, 2009)

\begin{tabular}{lcc}
\hline Linguistic importance & Fuzzy scale & Reciprocal scale \\
\hline Equally important & $(1,1,1)$ & $(1,1,1)$ \\
\hline Weekly more important & $(1 / 2,1,3 / 2)$ & $(2 / 3,1,2)$ \\
\hline Strongly more important & $(3 / 2,2,5 / 2)$ & $(2 / 5,1 / 2,2 / 3)$ \\
\hline
\end{tabular}


This is a copy of the "Post-print" (i.e., the authors' final draft, post-refereeing). Published as:

Abdul-Rahman, H., Wang, C., Wood, L. C., \& Ebrahimi, M. (in press). Integrating and ranking sustainability criteria for housing. Engineering Sustainability.

\begin{tabular}{lll}
\hline Very strongly more important & $(5 / 2,3,7 / 2)$ & $(2 / 7,1 / 3,2 / 5)$ \\
\hline Absolutely more important & $(7 / 2,4,9 / 2)$ & $(2 / 9,1 / 4,2 / 7)$ \\
\hline
\end{tabular}

\section{Step 5: Combining experts' views}

In this step the experts' views were combined. Fuzzy averaging was applied to combine the fuzzy matrices.

\section{Step 6: Converting fuzzy numbers to crisp numbers}

The combined fuzzy matrices were defuzzified to real matrices using the maximum formula as presented in Eq. 1

$$
\frac{m_{1}+4 m_{M}+m_{2}}{6} \quad x_{\max }^{(3)}=
$$

This formula has been applied for every member of the combined matrices.

\section{Step 7: Extraction of eigenvectors}

The eigenvector of each matrix were calculated using Microsoft Excel 2012. Firstly, the ”matrix.xla extension" was added to the Excel software then the MEigenvecMax function was used. This function computes eigenvector of a matrix regarding its maximum eigenvalue. This vector determines the importance weighting of each level. Finally, the weight of each criterion was computed by multiplying the weights of each level. The detailed calculations of Fuzzy-AHP are presented in the next section.

\subsection{DATA INTERPRETATION AND ANALYSIS}

The seven steps using Fuzzy-AHP were conducted and the relevant matrices were depicted and analysed to determine priority weights of each criterion and sub-criterion.

\subsection{Hierarchy and Matrices}

\section{Step 1: Establishment of hierarchy}


This is a copy of the "Post-print" (i.e., the authors' final draft, post-refereeing). Published as:

Abdul-Rahman, H., Wang, C., Wood, L. C., \& Ebrahimi, M. (in press). Integrating and ranking sustainability criteria for housing. Engineering Sustainability.

The original hierarchy consists of three sub-hierarchies: Environmental Sustainability, Social Sustainability, and Economic Sustainability, which were depicted earlier in Figures 1, 2, 3, respectively.

\section{Step 2: Establishment of pairwise comparison matrices}

The pairwise comparisons were conducted using linguistic variables for each pair of criteria. There were 20 blocks of factors. For each block a comparison matrix was established. Table 6 is the comparison matrix of Level 1 which consists of the three principal sustainability criteria; i.e., environmental, economical, and societal factors. Table 7 and Table 8 are the comparison matrices of the Level 2 and Level 3 under the environmental category, respectively. Likewise, Table 9 and 10 are for the social criteria, and Table 11 and 12 are for the economic criteria in respective levels.

Table 6: Level 1- Comparison Matrix of Sustainability Criteria

\begin{tabular}{cccc}
\hline $\begin{array}{c}\text { Sustainability } \\
\text { Criteria }\end{array}$ & EnS & EcS & ScS \\
\hline EnS & 1 & 0.333333 & 2 \\
\hline EcS & 3 & 1 & 3 \\
\hline ScS & 0.5 & 0.333333 & 1
\end{tabular}

Note: EnS = Environmental sustainability; EcS = Economic sustainability; ScS = Social sustainability

Table 7: Level 2- Comparison Matrix of Environmental Criteria

\begin{tabular}{c|c|c|c|c|c|c}
\hline $\begin{array}{c}\text { Environmental } \\
\text { Criteria }\end{array}$ & SSC & WEC & EAC & MRC & IEQ & IDPC \\
\hline SSC & 1 & 0.333333 & 0.5 & 0.5 & 0.5 & 0.5 \\
\hline WEC & 3 & 1 & 1 & 0.5 & 1 & 2 \\
\hline EAC & 2 & 1 & 1 & 0.5 & 0.5 & 1 \\
\hline MRC & 2 & 2 & 2 & 1 & 1 & 2 \\
\hline IEQ & 2 & 1 & 2 & 1 & 1 & 2 \\
\hline IDPC & 2 & 0.5 & 1 & 0.5 & 0.5 & 1 \\
\hline
\end{tabular}

Note: SSC = Sustainable Site Considerations; WEC = Water Efficiency Considerations;

$\mathrm{EAC}=$ Energy and Atmosphere Considerations; $\mathrm{MRC}=$ Materials and Resources Considerations;

IEQ = Indoor Environmental Quality; IDPC = Innovation and Design Process Considerations

Table 8: Level 3- Comparison matrix of Sub-criteria in Environmental Sustainability

\begin{tabular}{|c|c|c|c|c|c|}
\hline \multicolumn{5}{|c|}{ Matrix SSC: Comparison matrix of Sustainable Site Considerations } & \multirow{6}{*}{$\begin{array}{l}\text { LSC=Land Sensitivity Considerations; } \\
\text { PRC=Pollution Reduction Considerations; } \\
\text { DDA = Developing Damaged Areas; } \\
\text { EP = Ecosystem Preservation }\end{array}$} \\
\hline $\begin{array}{c}\text { Sustainable Site } \\
\text { Considerations }\end{array}$ & LSC & PRC & DDA & $\mathrm{EP}$ & \\
\hline LSC & 1 & 1 & 2 & 2 & \\
\hline PRC & 1 & 1 & 1 & 2 & \\
\hline DDA & 0.5 & 1 & 1 & 2 & \\
\hline $\mathrm{EP}$ & 0.5 & 0.5 & 0.5 & 1 & \\
\hline
\end{tabular}


This is a copy of the "Post-print" (i.e., the authors' final draft, post-refereeing). Published as:

Abdul-Rahman, H., Wang, C., Wood, L. C., \& Ebrahimi, M. (in press). Integrating and ranking sustainability criteria for housing. Engineering Sustainability.

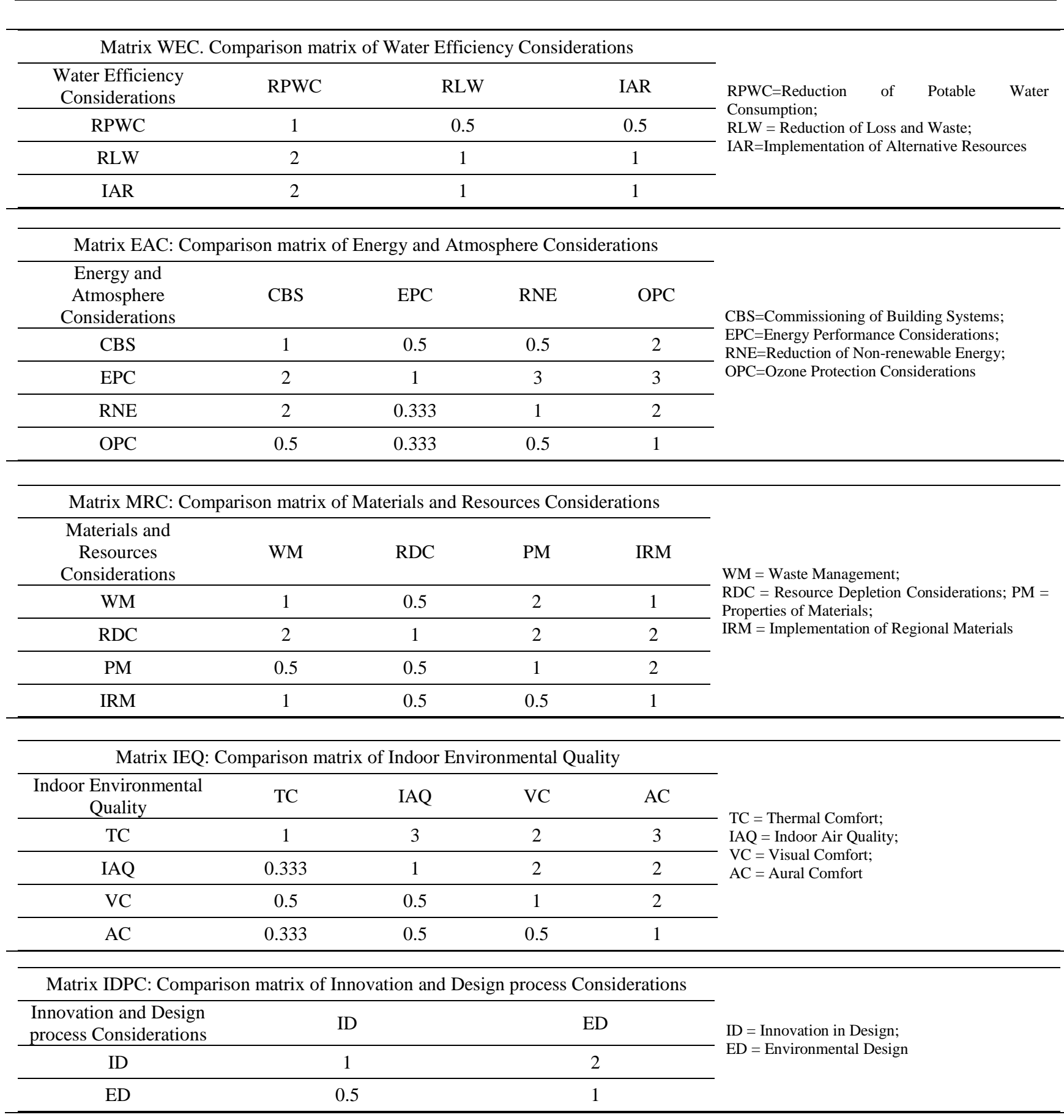

Table 9: Level 2- Comparison matrix of Social criteria

\begin{tabular}{ccccccc}
\hline Social criteria & SEC & HCC & JO & SI & SR & AI \\
\hline SEC & 1 & 2 & 1 & 1 & 1 & 0.5 \\
\hline HCC & 0.5 & 1 & 2 & 0.333 & 0.333 & 2 \\
\hline JO & 1 & 0.5 & 1 & 0.333 & 0.5 & 0.5 \\
\hline SI & 1 & 3 & 3 & 1 & 2 & 2 \\
\hline SR & 1 & 3 & 2 & 0.5 & 1 & 2 \\
\hline AI & 2 & 0.5 & 2 & 0.5 & 0.5 & 1 \\
\hline
\end{tabular}

Note: SEC = Site and Equipment Considerations; HCC = Health and Comfort Considerations;

JO = Job Opportunities; SI = Safety Issues; SR = Stakeholders' Relationship; AI = Architectural Issues 
This is a copy of the "Post-print" (i.e., the authors' final draft, post-refereeing). Published as:

Abdul-Rahman, H., Wang, C., Wood, L. C., \& Ebrahimi, M. (in press). Integrating and ranking sustainability criteria for housing. Engineering Sustainability.

Table 10: Level 3- Comparison Matrix of Sub-criteria in Social Sustainability

Matrix SEC: Comparison matrix of Site and Equipment Considerations

\begin{tabular}{|c|c|c|c|c|c|c|}
\hline $\begin{array}{l}\text { Site and Equipment } \\
\text { Considerations }\end{array}$ & QI & SS & $\mathrm{QF}$ & BBEC & LUC & \multirow{6}{*}{$\begin{array}{l}\text { QI = Quality of Infrastructure; } \\
\text { SS = Security of the Site; } \\
\text { QF = Quality of Facilities; } \\
\text { BBEC = Barrier-free Built Environment Considerations; } \\
\text { LUC = Land Use Considerations }\end{array}$} \\
\hline QI & 1 & 2 & 1 & 2 & 2 & \\
\hline SS & 0.5 & 1 & 1 & 3 & 2 & \\
\hline $\mathrm{QF}$ & 1 & 1 & 1 & 3 & 2 & \\
\hline BBEC & 0.5 & 0.333 & 0.333 & 1 & 0.5 & \\
\hline LUC & 0.5 & 0.5 & 0.5 & 2 & 1 & \\
\hline
\end{tabular}

Matrix HCC: Comparison matrix of Health and Comfort Considerations

\begin{tabular}{|c|c|c|c|c|c|c|c|}
\hline $\begin{array}{l}\text { Health and Comfort } \\
\text { considerations }\end{array}$ & THC & VIC & ACC & INAQ & DES & $\mathrm{IH}$ & \multirow{7}{*}{$\begin{array}{l}\text { THC = THermal Comfort; } \\
\text { VIC = VIsual Comfort; } \\
\text { ACC = ACoustical Comfort; } \\
\text { INAQ = INdoor Air Quality; } \\
\text { DES = Daylight and Exposure to Sunlight; } \\
\text { IH = Indoor Hygiene }\end{array}$} \\
\hline THC & 1 & 3 & 3 & 0.5 & 0.333 & 0.333 & \\
\hline VIC & 0.333 & 1 & 2 & 0.5 & 0.333 & 0.333 & \\
\hline ACC & 0.333 & 0.5 & 1 & 0.333 & 0.333 & 0.333 & \\
\hline INAQ & 2 & 2 & 3 & 1 & 0.333 & 0.333 & \\
\hline DES & 3 & 3 & 3 & 3 & 1 & 3 & \\
\hline $\mathrm{IH}$ & 3 & 3 & 3 & 3 & 0.333 & 1 & \\
\hline
\end{tabular}

\begin{tabular}{|c|c|c|c|}
\hline \multicolumn{3}{|c|}{ Matrix JO: Comparison matrix of Job Opportunities } & \multirow{4}{*}{$\begin{array}{l}\mathrm{DE}=\text { Direct Employment; } \\
\mathrm{IE}=\text { Indirect Employment }\end{array}$} \\
\hline Job Opportunities & $\mathrm{DE}$ & $\mathrm{IE}$ & \\
\hline $\mathrm{DE}$ & 1 & 0.5 & \\
\hline IE & 2 & 1 & \\
\hline
\end{tabular}

\begin{tabular}{|c|c|c|c|}
\hline \multicolumn{3}{|c|}{ Matrix SI: Comparison matrix of Safety Issues } & \multirow{4}{*}{$\begin{array}{l}\text { DCS = Design Considerations towards Safety; } \\
\text { MCS = Management Considerations towards Safety }\end{array}$} \\
\hline Safety Issues & DCS & MCS & \\
\hline DCS & 1 & 3 & \\
\hline MCS & 0.333 & 1 & \\
\hline
\end{tabular}

\begin{tabular}{|c|c|c|c|c|}
\hline \multicolumn{3}{|c|}{ Matrix SR: Comparison matrix of Stakeholders’ Relationship } & \multirow{4}{*}{$\begin{array}{l}\mathrm{CP}=\text { Communication to the Public; } \\
\mathrm{PP}=\text { Public Participation }\end{array}$} & \\
\hline $\begin{array}{c}\text { Stakeholders' } \\
\text { Relationship }\end{array}$ & $\mathrm{CP}$ & PP & & \\
\hline $\mathrm{CP}$ & 1 & 2 & & \\
\hline PP & 0.5 & 1 & & \\
\hline \multicolumn{3}{|c|}{ Matrix AI: Comparison matrix of Architectural Issues } & \multirow{4}{*}{$\begin{array}{l}\text { AHC }=\text { Architectural Heritage Considerations; } \\
\text { AFFC=Architectural Functionality and } \\
\text { Considerations }\end{array}$} & \multirow{4}{*}{ Flexibility } \\
\hline Architectural Issues & AHC & AFFC & & \\
\hline AHC & 1 & 1 & & \\
\hline AFFC & 1 & 1 & & \\
\hline
\end{tabular}

Table 11: Level 2- Comparison Matrix of Economic Criteria

\begin{tabular}{ccccc}
\hline $\begin{array}{c}\text { Economic } \\
\text { Criteria }\end{array}$ & EX & REV & IIRD & ILEE \\
\hline EX & 1 & 2 & 2 & 1 \\
\hline REV & 0.5 & 1 & 1 & 1 \\
\hline IIRD & 0.5 & 1 & 1 & 0.5 \\
\hline
\end{tabular}


This is a copy of the "Post-print" (i.e., the authors' final draft, post-refereeing). Published as:

Abdul-Rahman, H., Wang, C., Wood, L. C., \& Ebrahimi, M. (in press). Integrating and ranking sustainability criteria for housing. Engineering Sustainability.

$\begin{array}{lllll}\text { ILEE } & 1 & 1 & 2 & 1\end{array}$

Note: EX = EXpenditure; REV = REVenue; IIRD = Investment in Innovation,

Research and Development; ILEE = Improvement of Local Economic Environment

Table 12: Level 3- Comparison matrix of Sub-criteria in Economic Sustainability

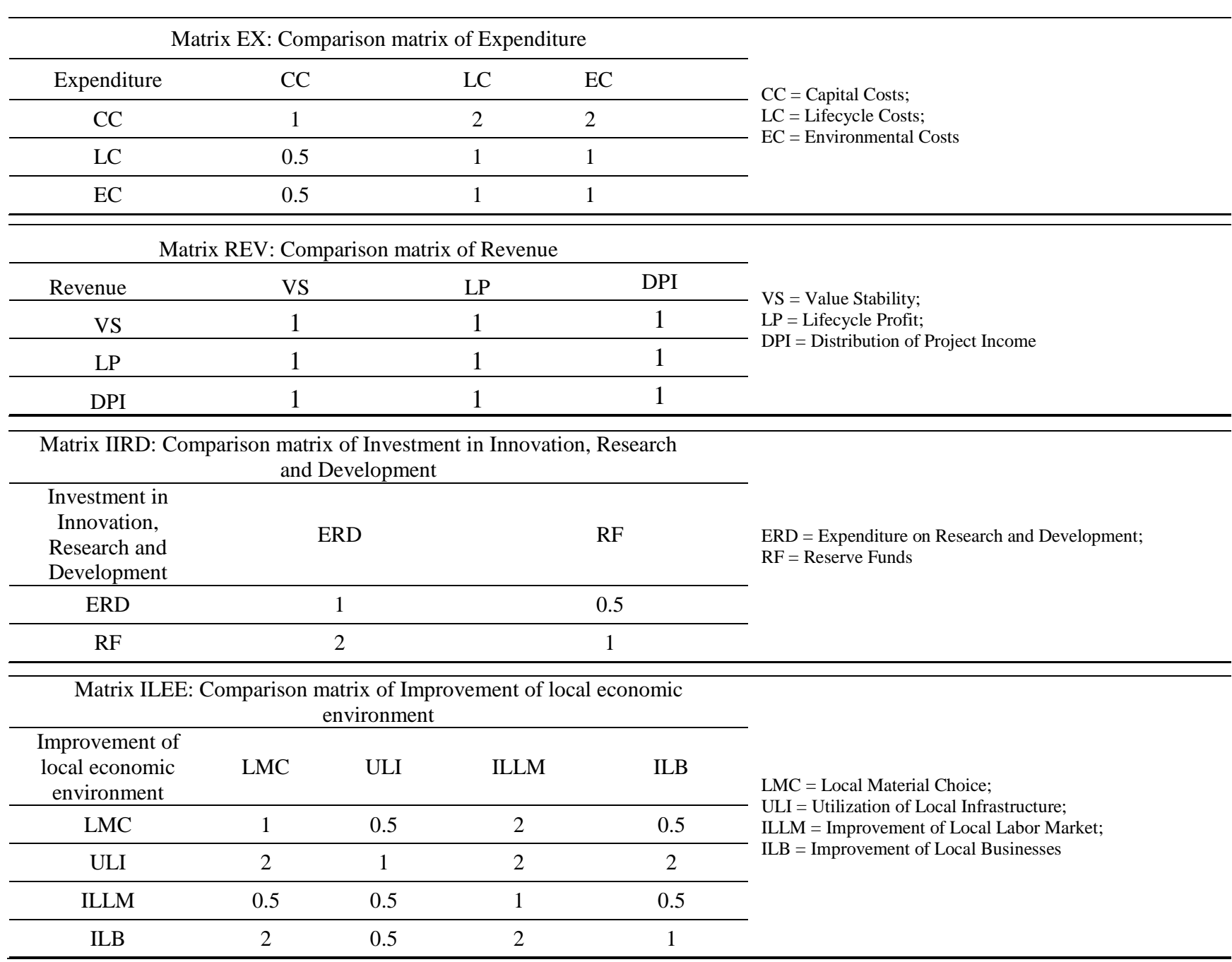

\section{Step 3: Calculating the consistency ratio of each comparison matrix}

This step ensures all experts have given consistent responses to the questions. The consistency ratios of all block of criteria were perfectly under 0.1 level therefore acceptable.

\section{Step 4: Converting linguistic judgment variables to fuzzy numbers}

The linguistic variables to which experts referred for comparisons of pair criteria were converted to fuzzy numbers. 
This is a copy of the "Post-print" (i.e., the authors' final draft, post-refereeing). Published as:

Abdul-Rahman, H., Wang, C., Wood, L. C., \& Ebrahimi, M. (in press). Integrating and ranking sustainability criteria for housing. Engineering Sustainability.

\section{Step 5: Combining experts' views}

The experts' views were combined. Fuzzy averaging operations were conducted for each block of criteria. Table 13 to Table 19 present the averages of each block of criteria.

Table 13: Fuzzy Averaging of Sustainability Criteria Block

\begin{tabular}{cccc}
\hline $\begin{array}{c}\text { Sustainability } \\
\text { Criteria }\end{array}$ & EnS & EcS & ScS \\
\hline EnS & $(1,1,1)$ & $(1.741,2.119,2.510)$ & $(0.986,1.071,1.167)$ \\
\hline EcS & $(0.792,0.976,1.181)$ & $(1,1,1)$ & $(0.737,0.857,1.005)$ \\
\hline ScS & $(0.986,1.071,1.167)$ & $(1.684,2.048,2.414)$ & $(1,1,1)$ \\
\hline
\end{tabular}

Table 14: Fuzzy Averaging of Environmental Criteria Block

\begin{tabular}{|c|c|c|c|c|c|c|}
\hline IDPC & $\begin{array}{c}(0.893,1.190 \\
1.605)\end{array}$ & $\begin{array}{c}(1.350,1.762, \\
2.271)\end{array}$ & $\begin{array}{c}(1.667,2, \\
2.429)\end{array}$ & $\begin{array}{c}(1.667,2.143 \\
2.714)\end{array}$ & $\begin{array}{c}(1.367,1.786, \\
2.310)\end{array}$ & $(1,1,1)$ \\
\hline IEQ & $\begin{array}{c}0.522,0.690, \\
0.986)\end{array}$ & $\begin{array}{c}0.836,0.976 \\
1.224)\end{array}$ & $\begin{array}{c}1.129,1.357, \\
1.595)\end{array}$ & $\begin{array}{c}1.310,1.571, \\
1.929)\end{array}$ & $(1,1,1)$ & $\begin{array}{c}0.555,0.762, \\
1.010)\end{array}$ \\
\hline MRC & $\begin{array}{c}0.569,0.655, \\
0.860)\end{array}$ & $\begin{array}{c}0.505,0.667, \\
0.948)\end{array}$ & $\begin{array}{c}0.914,1.214 \\
1.524) \\
\end{array}$ & $(1,1,1)$ & $\begin{array}{c}0.677,0.810, \\
1.043) \\
\end{array}$ & $\begin{array}{c}0.403,0.571, \\
0.862)\end{array}$ \\
\hline EAC & $\begin{array}{c}0.428,0.488, \\
0.584)\end{array}$ & $\begin{array}{c}0.701,0.726 \\
0.765)\end{array}$ & $(1,1,1)$ & $\begin{array}{c}(0.805,1, \\
1.405)\end{array}$ & $\begin{array}{c}0.836,0.976, \\
1.224)\end{array}$ & $\begin{array}{c}0.544,0.655, \\
0.788)\end{array}$ \\
\hline WEC & $\begin{array}{c}0.839,0.952, \\
1.090) \\
\end{array}$ & $(1,1,1)$ & $\begin{array}{c}1.643,1.857, \\
2.071) \\
\end{array}$ & $\begin{array}{c}(1.452,1.857, \\
2.357) \\
\end{array}$ & $\begin{array}{c}1.129,1.357, \\
1.595) \\
\end{array}$ & $\begin{array}{c}0.727,0.964, \\
1.327) \\
\end{array}$ \\
\hline SSC & $(1,1,1)$ & $\begin{array}{c}(1.469,1.762, \\
2.057) \\
\end{array}$ & $\begin{array}{c}2,2.429, \\
2.857\end{array}$ & $\begin{array}{c}(1.643,2, \\
2.357) \\
\end{array}$ & $\begin{array}{c}1.310,1.714, \\
2.214) \\
\end{array}$ & $\begin{array}{c}1.136,1.476, \\
1.914)\end{array}$ \\
\hline $\begin{array}{c}\text { Environmental } \\
\text { Criteria }\end{array}$ & SSC & WEC & EAC & MRC & IEQ & IDPC \\
\hline
\end{tabular}

Table 15: Fuzzy Averaging of Sub-criteria in Environmental Sustainability

\begin{tabular}{|c|c|c|c|c|}
\hline $\begin{array}{l}\text { Sustainable Site } \\
\text { Considerations }\end{array}$ & LSC & PRC & DDA & EP \\
\hline LSC & $(1,1,1)$ & $(0.710,0.738,0.781)$ & $(0.627,0.762,0.938)$ & $(0.824,1.024,1.257)$ \\
\hline PRC & $(1.500,1.714,1.929)$ & $(1,1,1)$ & $(0.781,1,1.333)$ & $(1.003,1.262,1.724)$ \\
\hline DDA & $(1.414,1.786,2.167)$ & $(0.938,1.214,1.595)$ & $(1,1,1)$ & $(0.955,1.262,1.867)$ \\
\hline EP & $(1.455,1.833,2.224)$ & $(0.955,1.262,1.581)$ & $(0.884,1.262,1.652)$ & $(1,1,1)$ \\
\hline $\begin{array}{l}\text { Water Efficiency } \\
\text { Considerations }\end{array}$ & RPWC & \multicolumn{2}{|c|}{ RLW } & IAR \\
\hline RPWC & $(1,1,1)$ & \multicolumn{2}{|c|}{$(0.521,0.571,0.653)$} & $(0.665,0.833,1.129)$ \\
\hline RLW & $(1.929,2.286,2.643)$ & \multicolumn{2}{|c|}{$(1,1,1)$} & $(1.357,1.714,2.071)$ \\
\hline IAR & $(1.271,1.643,2.024)$ & \multicolumn{2}{|c|}{$(0.615,0.738,1.067)$} & $(1,1,1)$ \\
\hline $\begin{array}{c}\text { Energy and } \\
\text { Atmosphere } \\
\text { Considerations }\end{array}$ & CBS & EPC & RNE & OPC \\
\hline CBS & $(1,1,1)$ & $(0.717,0.833,1.152)$ & $(0.663,0.881,1.210)$ & $(1.186,1.429,1.690)$ \\
\hline EPC & $(1.143,1.429,1.714)$ & $(1,1,1)$ & $(1.081,1.357,1.738)$ & $(1.557,1.929,2.310)$ \\
\hline RNE & $(1.295,1.500,2.095)$ & $(0.765,0.976,1.295)$ & $(1,1,1)$ & $(1.414,1.786,2.167)$ \\
\hline OPC & $(0.869,1.048,1.248)$ & $(0.610,0.738,0.900)$ & $(0.627,0.762,0.938)$ & $(1,1,1)$ \\
\hline $\begin{array}{l}\text { Materials and } \\
\text { Resources } \\
\text { Considerations }\end{array}$ & WM & $\mathrm{RDC}$ & PM & IRM \\
\hline
\end{tabular}


This is a copy of the "Post-print" (i.e., the authors' final draft, post-refereeing). Published as:

Abdul-Rahman, H., Wang, C., Wood, L. C., \& Ebrahimi, M. (in press). Integrating and ranking sustainability criteria for housing. Engineering Sustainability.

\begin{tabular}{|c|c|c|c|c|}
\hline WM & $(1,1,1)$ & $(0.662,0.857,1.262)$ & $(0.850,1.048,1.343)$ & $(0.638,0.857,1.190)$ \\
\hline $\mathrm{RDC}$ & $(0.952,1.286,1.714)$ & $(1,1,1)$ & $(1.010,1.357,1.810)$ & $(0.900,1.143,1.405)$ \\
\hline PM & $(1.010,1.214,1.524)$ & $(0.695,0.929,1.286)$ & $(1,1,1)$ & $(0.844,1.083,1.444)$ \\
\hline IRM & $(1.024,1.286,1.643)$ & $(0.924,1.143,1.476)$ & $(0.781,1,1.333)$ & $(1,1,1)$ \\
\hline $\begin{array}{c}\text { Indoor } \\
\text { Environmental } \\
\text { Quality } \\
\end{array}$ & TC & IAQ & VC & $\mathrm{AC}$ \\
\hline TC & $(1,1,1)$ & $(0.915,1.095,1.471)$ & $(0.843,1.214,1.595)$ & $(1.295,1.643,2.095)$ \\
\hline IAQ & $(1.184,1.476,1.771)$ & $(1,1,1)$ & $(1.357,1.857,2.357)$ & $(1.429,1.857,2.286)$ \\
\hline VC & $(0.757,1,1.548)$ & $(0.482,0.667,1.162)$ & $(1,1,1)$ & $(1.207,1.476,1.843)$ \\
\hline $\mathrm{AC}$ & $(0.663,0.881,1.210)$ & $(0.529,0.667,1.019)$ & $(0.869,1.048,1.248)$ & $(1,1,1)$ \\
\hline $\begin{array}{l}\text { Innovation and } \\
\text { Design process } \\
\text { Considerations }\end{array}$ & \multicolumn{2}{|c|}{ ID } & \multicolumn{2}{|c|}{ ED } \\
\hline ID & \multicolumn{2}{|c|}{$(1,1,1)$} & \multicolumn{2}{|c|}{$(0.806,1.048,1.300)$} \\
\hline ED & \multicolumn{2}{|c|}{$(1.622,1.976,2.438)$} & \multicolumn{2}{|c|}{$(1,1,1)$} \\
\hline
\end{tabular}

Table 16: Fuzzy Averaging of Social Criteria Block

\begin{tabular}{|c|c|c|c|c|c|c|}
\hline AI & $\begin{array}{c}\text { (0.813, 1.036 } \\
1.374)\end{array}$ & $\begin{array}{c}(1.398,1.762, \\
2.129)\end{array}$ & $\begin{array}{c}(1.169,1.405, \\
1.652)\end{array}$ & $\begin{array}{c}(1.738,2.143, \\
2.643)\end{array}$ & $\begin{array}{c}(0.836,0.976 \\
1.224)\end{array}$ & $(1,1,1)$ \\
\hline SR & $\begin{array}{c}0.624,0.810 \\
1.019)\end{array}$ & $\begin{array}{c}1.207,1.619, \\
2.129)\end{array}$ & $\begin{array}{c}(0.914,1.214, \\
1.524)\end{array}$ & $\begin{array}{c}(2.071,2.571, \\
3.071)\end{array}$ & $(1,1,1)$ & $\begin{array}{c}1.129,1.357, \\
1.595)\end{array}$ \\
\hline SI & $\begin{array}{c}(0.415,0.488, \\
0.665) \\
\end{array}$ & $\begin{array}{c}\text { (0.529, 0.667, } \\
1.019) \\
\end{array}$ & $\begin{array}{c}(0.365,0.500, \\
0.671)\end{array}$ & $(1,1,1)$ & $\begin{array}{c}(0.342,0.417 \\
0.536) \\
\end{array}$ & $\begin{array}{c}0.480,0.631, \\
0.893) \\
\end{array}$ \\
\hline JO & $\begin{array}{c}(0.387,0.548 \\
0.824)\end{array}$ & $\begin{array}{c}(1.095,1.571, \\
2.143)\end{array}$ & $(1,1,1)$ & $\begin{array}{c}(1.810,2.286 \\
2.857)\end{array}$ & $\begin{array}{c}(0.827,1.048, \\
1.557)\end{array}$ & $\begin{array}{c}(1.012,1.190 \\
1.390)\end{array}$ \\
\hline HCC & $\begin{array}{c}(0.607,0.750 \\
0.998) \\
\end{array}$ & $(1,1,1)$ & $\begin{array}{c}\text { (0.512, 0.762, } \\
1.319) \\
\end{array}$ & $\begin{array}{c}\text { (1.429, 1.857, } \\
2.286) \\
\end{array}$ & $\begin{array}{c}\text { (0.736, 0.976, } \\
1.343) \\
\end{array}$ & $\begin{array}{c}(0.791,0.952 \\
1.233) \\
\end{array}$ \\
\hline SEC & $(1,1,1)$ & $\begin{array}{c}1.843,2.214, \\
2.595)\end{array}$ & $\begin{array}{c}(1.810,2.286, \\
2.857)\end{array}$ & $\begin{array}{c}(2.429,2.857, \\
3.286)\end{array}$ & $\begin{array}{c}(1.438,1.786, \\
2.238)\end{array}$ & $\begin{array}{c}(1.257,1.571, \\
1.905)\end{array}$ \\
\hline $\begin{array}{l}\text { Social } \\
\text { Criteria }\end{array}$ & SEC & HCC & JO & SI & SR & AI \\
\hline
\end{tabular}

Table 17: Fuzzy Averaging of Sub-criteria in Social Sustainability

\begin{tabular}{|c|c|c|c|c|c|c|c|c|c|}
\hline $\begin{array}{c}\text { Site and } \\
\text { Equipment } \\
\text { Considerations } \\
\end{array}$ & QI & \multicolumn{2}{|l|}{ SS } & \multicolumn{2}{|c|}{$\mathrm{QF}$} & \multicolumn{2}{|c|}{ BBEC } & \multicolumn{2}{|r|}{ LUC } \\
\hline QI & $(1,1,1)$ & \multicolumn{2}{|c|}{$\begin{array}{c}(1.107,1.333, \\
1.676)\end{array}$} & \multicolumn{2}{|c|}{$\begin{array}{c}(0.660,0.821, \\
1.279)\end{array}$} & \multicolumn{2}{|c|}{$(0.695,0.786,1)$} & \multicolumn{2}{|c|}{$(0.724,0.929,1.238)$} \\
\hline SS & $\begin{array}{c}1.089,1.393 \\
1.707)\end{array}$ & \multicolumn{2}{|c|}{$(1,1,1)$} & \multicolumn{2}{|c|}{$\begin{array}{c}(0.822,1.048, \\
1.390)\end{array}$} & \multicolumn{2}{|c|}{$\begin{array}{c}0.365,0.500 \\
0.671) \\
\end{array}$} & \multicolumn{2}{|c|}{$(0.758,0.940,1.146)$} \\
\hline QF & $\begin{array}{c}(1.214,1.571 \\
1.929)\end{array}$ & \multicolumn{2}{|c|}{$\begin{array}{c}(1.114,1.429, \\
1.762)\end{array}$} & \multicolumn{2}{|c|}{$(1,1,1)$} & \multicolumn{2}{|c|}{$\begin{array}{c}(0.701,0.952, \\
1.400)\end{array}$} & \multicolumn{2}{|c|}{$(1.010,1.357,1.810)$} \\
\hline BBEC & $\begin{array}{c}1.143,1.429 \\
1.714)\end{array}$ & \multicolumn{2}{|c|}{$\begin{array}{c}(1.810,2.286, \\
2.857) \\
\end{array}$} & \multicolumn{2}{|c|}{$\begin{array}{c}1.152,1.500, \\
1.952)\end{array}$} & \multicolumn{2}{|c|}{$(1,1,1)$} & \multicolumn{2}{|c|}{$(1.5,1.857,2.214)$} \\
\hline LUC & $\begin{array}{c}0.905,1.143, \\
1.571) \\
\end{array}$ & \multicolumn{2}{|c|}{$(1.614,2,2.405)$} & $\begin{array}{r}0.695, \\
1.28 \\
\end{array}$ & 929 & \multicolumn{2}{|c|}{$\begin{array}{c}0.555,0.619, \\
0.724) \\
\end{array}$} & \multicolumn{2}{|r|}{$(1,1,1)$} \\
\hline $\begin{array}{l}\text { Health and } \\
\text { Comfort } \\
\text { considerations }\end{array}$ & THC & VIC & & ACC & \multicolumn{2}{|c|}{ INAQ } & \multicolumn{2}{|c|}{ DES } & $\mathrm{IH}$ \\
\hline THC & $(1,1,1)$ & $\begin{array}{c}(0.655,0.905 \\
1.462)\end{array}$ & & $\begin{array}{l}\text { 631, 0.905, } \\
1.39)\end{array}$ & $(1.3$ & $\begin{array}{l}\text { 1.714, } \\
1)\end{array}$ & $\begin{array}{r}(1.105,1 \\
1.81\end{array}$ & & $\begin{array}{c}(1.786,2.143 \\
2.5)\end{array}$ \\
\hline VIC & $\begin{array}{c}(1.057,1.5, \\
1.952) \\
\end{array}$ & $(1,1,1)$ & & $\begin{array}{l}152,1.357, \\
1.667)\end{array}$ & $\overline{(1.6}$ & $\begin{array}{l}2.143, \\
3) \\
\end{array}$ & $\begin{array}{r}(1.024,1 \\
1.92 \\
\end{array}$ & & $(1.643,2,2.357)$ \\
\hline ACC & $\begin{array}{c}(1.081,1.5, \\
2.024)\end{array}$ & $\begin{array}{c}(0.812,0.976 \\
1.152)\end{array}$ & & $(1,1,1)$ & $(1.57$ & 2.429) & $\begin{array}{c}(1.098,1 \\
1.72\end{array}$ & & $\begin{array}{c}(1.929,2.429, \\
2.929)\end{array}$ \\
\hline
\end{tabular}


This is a copy of the "Post-print" (i.e., the authors' final draft, post-refereeing). Published as:

Abdul-Rahman, H., Wang, C., Wood, L. C., \& Ebrahimi, M. (in press). Integrating and ranking sustainability criteria for housing. Engineering Sustainability.

\begin{tabular}{|c|c|c|c|c|c|c|}
\hline INAQ & $\begin{array}{c}0.615,0.738, \\
1.067)\end{array}$ & $\begin{array}{c}0.434,0.583 \\
0.955)\end{array}$ & $\begin{array}{c}(0.491,0.595 \\
0.829)\end{array}$ & $(1,1,1)$ & $\begin{array}{c}0.931,1.119, \\
1.51)\end{array}$ & $\begin{array}{c}0.986,1.214 \\
1.452)\end{array}$ \\
\hline DES & $\begin{array}{c}0.741,0.976 \\
1.224)\end{array}$ & $\begin{array}{c}0.598,0.833, \\
1.367)\end{array}$ & $\begin{array}{c}0.965,1.190 \\
1.533)\end{array}$ & $\begin{array}{c}1.041,1.333, \\
1.629)\end{array}$ & $(1,1,1)$ & $\begin{array}{c}0.850,1.190, \\
1.629)\end{array}$ \\
\hline IH & $\begin{array}{c}(0.522,0.571, \\
0.648)\end{array}$ & $\begin{array}{c}(0.590,0.702, \\
1.012)\end{array}$ & $\begin{array}{c}(0.373,0.476 \\
0.705)\end{array}$ & $\begin{array}{c}0.874,1.048, \\
1.414)\end{array}$ & $\begin{array}{c}0.876,1.143, \\
1.619)\end{array}$ & $(1,1,1)$ \\
\hline Job Opportunities & \multicolumn{3}{|c|}{$\mathrm{DE}$} & \multicolumn{3}{|c|}{ IE } \\
\hline $\mathrm{DE}$ & \multicolumn{3}{|c|}{$(1,1,1)$} & \multicolumn{3}{|c|}{$(1.200,1.500,1.810)$} \\
\hline IE & \multicolumn{3}{|c|}{$(0.750,0.905,1.176)$} & \multicolumn{3}{|c|}{$(1,1,1)$} \\
\hline Safety Issues & \multicolumn{3}{|c|}{ DCS } & \multicolumn{3}{|c|}{ MCS } \\
\hline DCS & \multicolumn{3}{|c|}{$(1,1,1)$} & \multicolumn{3}{|c|}{$(1.295,1.500,1.810)$} \\
\hline MCS & \multicolumn{3}{|c|}{$(0.796,0.952,1.114)$} & \multicolumn{3}{|c|}{$(1,1,1)$} \\
\hline $\begin{array}{l}\text { Stakeholders' } \\
\text { Relationship }\end{array}$ & \multicolumn{3}{|c|}{$\mathrm{CP}$} & \multicolumn{3}{|c|}{ PP } \\
\hline $\mathrm{CP}$ & \multicolumn{3}{|c|}{$(1,1,1)$} & \multicolumn{3}{|c|}{$(0.827,1.048,1.271)$} \\
\hline $\mathrm{PP}$ & \multicolumn{3}{|c|}{$(1.033,1.214,1.595)$} & \multicolumn{3}{|c|}{$(1,1,1)$} \\
\hline $\begin{array}{l}\text { Architectural } \\
\text { Issues }\end{array}$ & \multicolumn{3}{|c|}{$\mathrm{AHC}$} & \multicolumn{3}{|c|}{ AFFC } \\
\hline AHC & \multicolumn{3}{|c|}{$(1,1,1)$} & \multicolumn{3}{|c|}{$(0.648,0.810,1.090)$} \\
\hline AFFC & \multicolumn{3}{|c|}{$(1.414,1.786,2.167)$} & \multicolumn{3}{|c|}{$(1,1,1)$} \\
\hline
\end{tabular}

Table 18: Fuzzy Averaging of Economic Criteria Block

\begin{tabular}{ccccc}
\hline $\begin{array}{c}\text { Economic } \\
\text { Criteria }\end{array}$ & EX & REV & IIRD & ILEE \\
\hline EX & $(1,1,1)$ & $(1.067,1.286,1.619)$ & $(0.901,1.167,1.638)$ & $(0.648,0.810,1.090)$ \\
\hline $\operatorname{REV}$ & $(0.884,1.119,1.367)$ & $(1,1,1)$ & $(0.822,1.048,1.390)$ & $(0.663,0.881,1.210)$ \\
\hline $\operatorname{IIRD}$ & $(1.169,1.548,1.938)$ & $(1.114,1.429,1.762)$ & $(1,1,1)$ & $(0.771,0.929,1.381)$ \\
\hline $\operatorname{ILEE}$ & $(1.414,1.786,2.167)$ & $(1.295,1.643,2.095)$ & $(0.857,1.143,1.429)$ & $(1,1,1)$ \\
\hline
\end{tabular}

Table 19: Fuzzy Averaging of Sub-criteria in Economic Sustainability

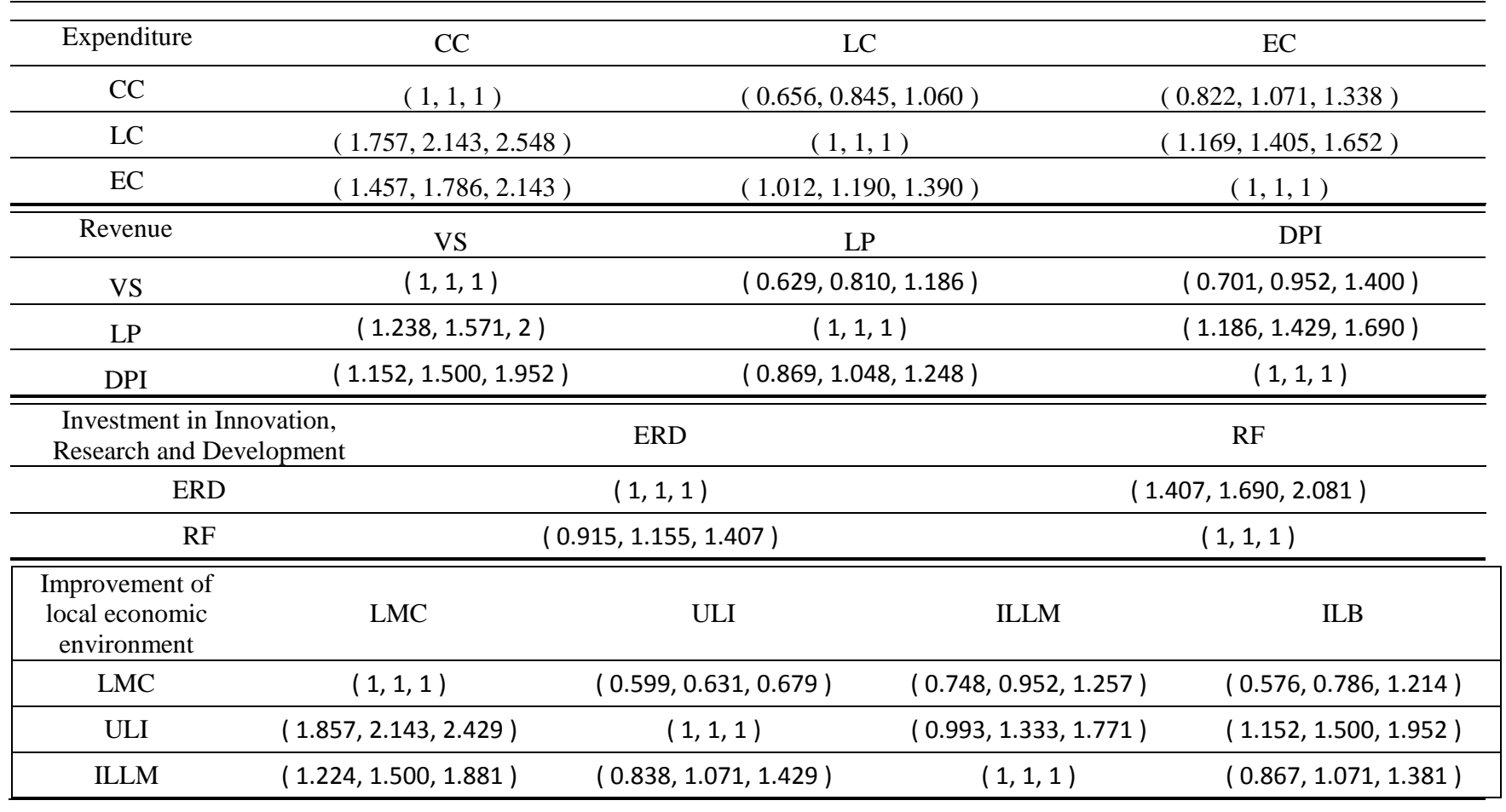


This is a copy of the "Post-print" (i.e., the authors' final draft, post-refereeing). Published as:

Abdul-Rahman, H., Wang, C., Wood, L. C., \& Ebrahimi, M. (in press). Integrating and ranking sustainability criteria for housing. Engineering Sustainability.

ILB $\quad(1.024,1.429,1.929) \quad(0.679,0.905,1.248) \quad(0.867,1.071,1.381) \quad(1,1,1)$

\section{Step 6: Converting fuzzy numbers to crisp numbers}

The fuzzy numbers in previous matrices were defuzzified into crisp numbers in Table 20 to Table 26.

Table 20: Crisp Matrix of Sustainability Criteria

\begin{tabular}{cccc}
\hline $\begin{array}{c}\text { Sustainability } \\
\text { Criteria }\end{array}$ & EnS & EcS & ScS \\
\hline EnS & 1 & 2.121 & 1.073 \\
\hline EcS & 0.980 & 1 & 0.862 \\
\hline ScS & 1.073 & 2.048 & 1 \\
\hline
\end{tabular}

Table 21: Crisp Matrix of Environmental Criteria

\begin{tabular}{ccccccc}
\hline $\begin{array}{c}\text { Environmental } \\
\text { Criteria }\end{array}$ & SSC & WEC & EAC & MRC & IEQ & IDPC \\
\hline SSC & 1 & 0.956 & 0.494 & 0.675 & 0.712 & 1.210 \\
\hline WEC & 1.762 & 1 & 0.728 & 0.687 & 0.994 & 1.778 \\
\hline EAC & 2.429 & 1.857 & 1 & 1.216 & 1.359 & 2.016 \\
\hline MRC & 2 & 1.873 & 1.035 & 1 & 1.587 & 2.159 \\
\hline IEQ & 1.730 & 1.359 & 0.994 & 0.826 & 1 & 1.803 \\
\hline IDPC & 1.493 & 0.985 & 0.659 & 0.592 & 0.769 & 1 \\
\hline
\end{tabular}

Table 22: Crisp Matrix of Sub-criteria in Environmental Sustainability

\begin{tabular}{|c|c|c|c|c|}
\hline Sustainable Site Considerations & LSC & PRC & DDA & EP \\
\hline LSC & 1 & 0.741 & 0.769 & 1.029 \\
\hline PRC & 1.714 & 1 & 1.019 & 1.296 \\
\hline DDA & 1.787 & 1.232 & 1 & 1.312 \\
\hline $\mathrm{EP}$ & 1.835 & 1.264 & 1.264 & 1 \\
\hline Water Efficiency Considerations & \multicolumn{2}{|c|}{ RPWC } & RLW & IAR \\
\hline RPWC & \multicolumn{2}{|c|}{1} & 0.577 & 0.854 \\
\hline RLW & \multicolumn{2}{|c|}{2.286} & 1 & 1.714 \\
\hline IAR & \multicolumn{2}{|c|}{1.644} & 0.772 & 1 \\
\hline Energy and Atmosphere Considerations & CBS & EPC & RNE & OPC \\
\hline CBS & 1 & 0.867 & 0.899 & 1.432 \\
\hline EPC & 1.429 & 1 & 1.375 & 1.930 \\
\hline RNE & 1.565 & 0.994 & 1 & 1.787 \\
\hline OPC & 1.051 & 0.744 & 0.769 & 1 \\
\hline Materials and Resources Considerations & WM & $\mathrm{RDC}$ & PM & IRM \\
\hline WM & 1 & 0.892 & 1.064 & 0.876 \\
\hline RDC & 1.302 & 1 & 1.375 & 1.146 \\
\hline PM & 1.232 & 0.949 & 1 & 1.104 \\
\hline IRM & 1.302 & 1.162 & 1.019 & 1 \\
\hline Indoor Environmental Quality & $\mathrm{TC}$ & IAQ & $\mathrm{VC}$ & $\mathrm{AC}$ \\
\hline TC & 1 & 1.128 & 1.216 & 1.660 \\
\hline
\end{tabular}


This is a copy of the "Post-print" (i.e., the authors' final draft, post-refereeing). Published as:

Abdul-Rahman, H., Wang, C., Wood, L. C., \& Ebrahimi, M. (in press). Integrating and ranking sustainability criteria for housing. Engineering Sustainability.

\begin{tabular}{ccccc}
\hline IAQ & 1.477 & 1 & 1.857 & 1.857 \\
\hline VC & 1.051 & 0.718 & 1.051 & 1.493 \\
\hline AC & 0.899 & 0.702 & ED & 1 \\
\hline Innovation \& Design Process & ID & & 1.049 \\
\hline ID & 1 & & 1 \\
\hline ED & 1.994 & & 1 \\
\hline
\end{tabular}

Table 23: Crisp Matrix of Social Criteria

\begin{tabular}{ccccccc}
\hline $\begin{array}{c}\text { Social } \\
\text { criteria }\end{array}$ & SEC & HCC & JO & SI & SR & AI \\
\hline SEC & 1 & 0.767 & 0.567 & 0.505 & 0.814 & 1.055 \\
\hline HCC & 2.216 & 1 & 1.587 & 0.702 & 1.635 & 1.762 \\
\hline JO & 2.302 & 0.813 & 1 & 0.506 & 1.216 & 1.407 \\
\hline SI & 2.857 & 1.857 & 2.302 & 1 & 2.571 & 2.159 \\
\hline SR & 1.803 & 0.997 & 1.096 & 0.424 & 1 & 0.994 \\
\hline AI & 1.575 & 0.972 & 1.194 & 0.650 & 1.359 & 1 \\
\hline
\end{tabular}

Table 24: Crisp Matrix of Sub-criteria in Social Sustainability

\begin{tabular}{|c|c|c|c|c|c|c|}
\hline Site and Equipment Considerations & QI & \multicolumn{2}{|r|}{ SS } & QF & BBEC & LUC \\
\hline QI & 1 & \multicolumn{2}{|r|}{1.395} & 1.571 & 1.429 & 1.175 \\
\hline SS & 1.353 & \multicolumn{2}{|r|}{1} & 1.432 & 2.302 & 2.003 \\
\hline QF & 0.871 & \multicolumn{2}{|r|}{1.067} & 1 & 1.517 & 0.949 \\
\hline BBEC & 0.806 & \multicolumn{2}{|r|}{0.506} & 0.985 & 1 & 0.626 \\
\hline LUC & 0.946 & \multicolumn{2}{|r|}{0.944} & 1.375 & 1.857 & 1 \\
\hline Health and Comfort considerations & THC & VIC & ACC & INAQ & DES & $\mathrm{IH}$ \\
\hline THC & 1 & 1.502 & 1.517 & 0.772 & 0.978 & 0.576 \\
\hline VIC & 0.956 & 1 & 0.978 & 0.620 & 0.883 & 0.735 \\
\hline ACC & 0.940 & 1.375 & 1 & 0.617 & 1.210 & 0.497 \\
\hline INAQ & 1.714 & 2.143 & 2 & 1 & 1.334 & 1.080 \\
\hline DES & 1.390 & 1.444 & 1.407 & 1.153 & 1 & 1.178 \\
\hline $\mathrm{IH}$ & 2.143 & 2 & 2.429 & 1.216 & 1.207 & 1 \\
\hline Job Opportunities & & $\mathrm{DE}$ & & & IE & \\
\hline $\mathrm{DE}$ & & 1 & & & 1.502 & \\
\hline IE & & 0.924 & & & 1 & \\
\hline Safety Issues & & DCS & & & MCS & \\
\hline DCS & & 1 & & & 1.517 & \\
\hline MCS & & 0.953 & & & 1 & \\
\hline Stakeholders' Relationship & & $\mathrm{CP}$ & & & $\mathrm{PP}$ & \\
\hline $\mathrm{CP}$ & & 1 & & & 1.048 & \\
\hline PP & & 1.248 & & & 1 & \\
\hline Architectural Issues & & $\mathrm{AHC}$ & & & AFFC & \\
\hline AHC & & 1 & & & 0.829 & \\
\hline AFFC & & 1.787 & & & 1 & \\
\hline
\end{tabular}


This is a copy of the "Post-print" (i.e., the authors' final draft, post-refereeing). Published as:

Abdul-Rahman, H., Wang, C., Wood, L. C., \& Ebrahimi, M. (in press). Integrating and ranking sustainability criteria for housing. Engineering Sustainability.

Table25: Crisp Matrix of Economic Criteria

\begin{tabular}{ccccc}
\hline Economic Criteria & EX & REV & IIRD & ILEE \\
\hline EX & 1 & 1.305 & 1.201 & 0.829 \\
\hline REV & 1.121 & 1 & 1.067 & 0.899 \\
\hline IIRD & 1.550 & 1.432 & 1 & 0.978 \\
\hline ILEE & 1.787 & 1.660 & 1.143 & 1 \\
\hline
\end{tabular}

Table 26: Crisp Matrix of Sub-criteria in Economic Sustainability

\begin{tabular}{|c|c|c|c|c|}
\hline Expenditure & \multicolumn{2}{|l|}{$\mathrm{CC}$} & \multicolumn{2}{|c|}{ EC } \\
\hline $\mathrm{CC}$ & \multicolumn{2}{|l|}{1} & 0.850 & 1.074 \\
\hline LC & \multicolumn{2}{|l|}{2.146} & 1 & 1.407 \\
\hline EC & \multicolumn{2}{|l|}{1.790} & 1.194 & 1 \\
\hline Revenue & \multicolumn{2}{|l|}{ VS } & LP & DPI \\
\hline VS & \multicolumn{2}{|l|}{1} & 0.842 & 0.985 \\
\hline LP & \multicolumn{2}{|l|}{1.587} & 1 & 1.432 \\
\hline DPI & \multicolumn{2}{|l|}{1.517} & 1.051 & 1 \\
\hline Investment in Innovation, Research and Development & \multicolumn{2}{|c|}{ ERD } & \multicolumn{2}{|r|}{$\mathrm{RF}$} \\
\hline ERD & \multicolumn{2}{|c|}{1} & \multicolumn{2}{|r|}{1.708} \\
\hline $\mathrm{RF}$ & \multicolumn{2}{|c|}{1.157} & \multicolumn{2}{|r|}{1} \\
\hline Improvement of local economic environment & LMC & ULI & ILLM & ILB \\
\hline LMC & 1 & 0.634 & 0.969 & 0.822 \\
\hline ULI & 2.143 & 1 & 1.350 & 1.517 \\
\hline ILLM & 1.517 & 1.092 & 1 & 1.089 \\
\hline ILB & 1.444 & 0.924 & 1.089 & 1 \\
\hline
\end{tabular}

\section{Step 7: Extraction of eigenvector}

Within this step eigenvector of each matrix was computed. These vectors establish the weight of each level that should be normalized. The weight of each criterion was calculated by multiplying the weight for each level. Table 27, 28, and 29 present the final weight of sustainability criteria and sub-criteria for environmental, social, and economic, respectively.

Table 27: Final Weights of Environmental Criteria and Sub-criteria

\begin{tabular}{|c|c|c|c|c|c|c|c|}
\hline $\begin{array}{c}\text { Sustainability } \\
\text { objective }\end{array}$ & $\begin{array}{c}\text { Final } \\
\text { weight }\end{array}$ & $\begin{array}{l}\text { Sustainability } \\
\text { criterion }\end{array}$ & $\begin{array}{l}\text { Relative } \\
\text { weights of } \\
\text { criteria }\end{array}$ & $\begin{array}{c}\text { Final } \\
\text { weights of } \\
\text { criteria }\end{array}$ & Sustainability sub-criterion & $\begin{array}{c}\text { Relative } \\
\text { weights of } \\
\text { sub-criteria }\end{array}$ & $\begin{array}{l}\text { Final weights } \\
\text { of sub-criteria }\end{array}$ \\
\hline \multirow{6}{*}{$\begin{array}{l}\text { Environmental } \\
\text { Criteria }\end{array}$} & \multirow{6}{*}{0.371} & \multirow{4}{*}{$\begin{array}{l}\text { sustainable Site } \\
\text { Considerations }\end{array}$} & \multirow{4}{*}{0.114} & \multirow{4}{*}{0.0423} & $\begin{array}{l}\text { Land sensitivity } \\
\text { considerations }\end{array}$ & 0.187 & 0.0079 \\
\hline & & & & & $\begin{array}{l}\text { Pollution reduction } \\
\text { considerations }\end{array}$ & 0.260 & 0.0110 \\
\hline & & & & & Developing damaged areas & 0.276 & 0.0117 \\
\hline & & & & & Ecosystem preservation & 0.277 & 0.0117 \\
\hline & & \multirow{2}{*}{$\begin{array}{l}\text { Water Efficiency } \\
\text { Considerations }\end{array}$} & \multirow{2}{*}{0.152} & \multirow{2}{*}{0.0564} & $\begin{array}{l}\text { Reduction of potable water } \\
\text { consumption }\end{array}$ & 0.229 & 0.0129 \\
\hline & & & & & $\begin{array}{l}\text { Reduction of loss and } \\
\text { waste }\end{array}$ & 0.457 & 0.0258 \\
\hline
\end{tabular}


This is a copy of the "Post-print" (i.e., the authors' final draft, post-refereeing). Published as:

Abdul-Rahman, H., Wang, C., Wood, L. C., \& Ebrahimi, M. (in press). Integrating and ranking sustainability criteria for housing. Engineering Sustainability.

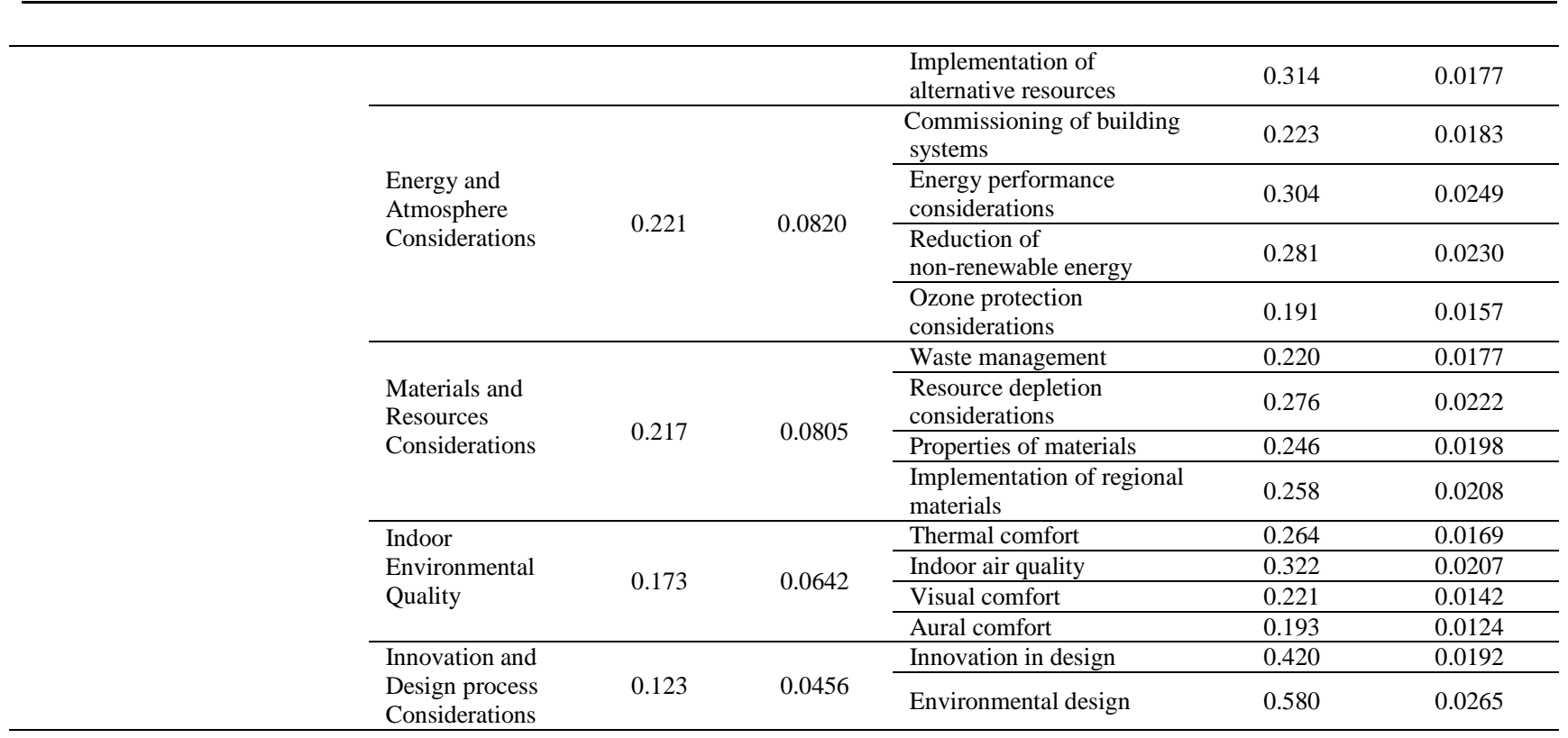

Table 28: Final Weights of Social Criteria and Sub-criteria

\begin{tabular}{|c|c|c|c|c|c|c|c|}
\hline $\begin{array}{l}\text { Sustainability } \\
\text { objective }\end{array}$ & $\begin{array}{l}\text { Final } \\
\text { weight }\end{array}$ & $\begin{array}{l}\text { Sustainability } \\
\text { criterion }\end{array}$ & $\begin{array}{l}\text { Relative } \\
\text { weights of } \\
\text { criteria }\end{array}$ & $\begin{array}{l}\text { Final } \\
\text { weights of } \\
\text { criteria }\end{array}$ & Sustainability sub-criterion & $\begin{array}{l}\text { Relative } \\
\text { weights of } \\
\text { sub-criteria }\end{array}$ & $\begin{array}{l}\text { Final weights of } \\
\text { sub-criteria }\end{array}$ \\
\hline \multirow[t]{19}{*}{ Social Criteria } & \multirow[t]{19}{*}{0.365} & \multirow{5}{*}{$\begin{array}{l}\text { Site and } \\
\text { Equipment } \\
\text { Considerations }\end{array}$} & \multirow{5}{*}{0.105} & \multirow{5}{*}{0.0383} & Quality of infrastructure & 0.225 & 0.0086 \\
\hline & & & & & Security of the site & 0.265 & 0.0102 \\
\hline & & & & & Quality of facilities & 0.181 & 0.0069 \\
\hline & & & & & $\begin{array}{l}\text { Barrier-free built } \\
\text { environment } \\
\text { considerations }\end{array}$ & 0.130 & 0.0050 \\
\hline & & & & & Land use considerations & 0.200 & 0.0077 \\
\hline & & \multirow{6}{*}{$\begin{array}{l}\text { Health and } \\
\text { Comfort } \\
\text { considerations }\end{array}$} & \multirow{6}{*}{0.189} & \multirow{6}{*}{0.0690} & Thermal comfort & 0.142 & 0.0098 \\
\hline & & & & & Visual comfort & 0.120 & 0.0083 \\
\hline & & & & & Acoustic comfort & 0.127 & 0.0088 \\
\hline & & & & & Indoor air quality & 0.209 & 0.0144 \\
\hline & & & & & $\begin{array}{l}\text { Daylight and exposure to } \\
\text { Sunlight }\end{array}$ & 0.178 & 0.0123 \\
\hline & & & & & Indoor hygiene & 0.224 & 0.0155 \\
\hline & & \multirow{2}{*}{ Job Opportunities } & \multirow{2}{*}{0.150} & \multirow[t]{2}{*}{0.0548} & Direct employment & 0.560 & 0.0307 \\
\hline & & & & & Indirect employment & 0.440 & 0.0241 \\
\hline & & \multirow[b]{2}{*}{ Safety Issues } & \multirow[b]{2}{*}{0.275} & \multirow[b]{2}{*}{0.1004} & $\begin{array}{l}\text { Design considerations } \\
\text { towards safety }\end{array}$ & 0.558 & 0.0560 \\
\hline & & & & & $\begin{array}{l}\text { Management } \\
\text { considerations towards } \\
\text { safety }\end{array}$ & 0.442 & 0.0444 \\
\hline & & \multirow{2}{*}{$\begin{array}{l}\text { Stakeholders' } \\
\text { Relationship }\end{array}$} & \multirow{2}{*}{0.134} & \multirow{2}{*}{0.0489} & $\begin{array}{l}\text { Communication to the } \\
\text { Public }\end{array}$ & 0.478 & 0.0234 \\
\hline & & & & & Public participation & 0.522 & 0.0255 \\
\hline & & \multirow{2}{*}{$\begin{array}{l}\text { Architectural } \\
\text { Issues }\end{array}$} & \multirow[b]{2}{*}{0.147} & \multirow[b]{2}{*}{0.0537} & $\begin{array}{l}\text { Architectural heritage } \\
\text { considerations }\end{array}$ & 0.405 & 0.0217 \\
\hline & & & & & $\begin{array}{l}\text { Architectural functionality } \\
\text { and flexibility } \\
\text { considerations }\end{array}$ & 0.595 & 0.0319 \\
\hline
\end{tabular}

Table 29: Final Weights of Economic Criteria and Sub-criteria

\begin{tabular}{cccccc}
\hline $\begin{array}{c}\text { Sustainability } \\
\text { objective }\end{array}$ & $\begin{array}{c}\text { Final } \\
\text { weight }\end{array}$ & $\begin{array}{c}\text { Sustainability } \\
\text { criterion }\end{array}$ & $\begin{array}{c}\text { Relative } \\
\text { weights of } \\
\text { criteria }\end{array}$ & $\begin{array}{c}\text { Final weights } \\
\text { of criteria }\end{array}$ & $\begin{array}{c}\text { Sustainability } \\
\text { sub-criterion }\end{array}$ \\
\hline $\begin{array}{c}\text { Economic } \\
\text { Criteria }\end{array}$ & 0.264 & Expenditure & 0.229 & 0.0605 & Capital costs \\
\cline { 3 - 5 } sub-criteria
\end{tabular}


This is a copy of the "Post-print" (i.e., the authors' final draft, post-refereeing). Published as:

Abdul-Rahman, H., Wang, C., Wood, L. C., \& Ebrahimi, M. (in press). Integrating and ranking sustainability criteria for housing. Engineering Sustainability.

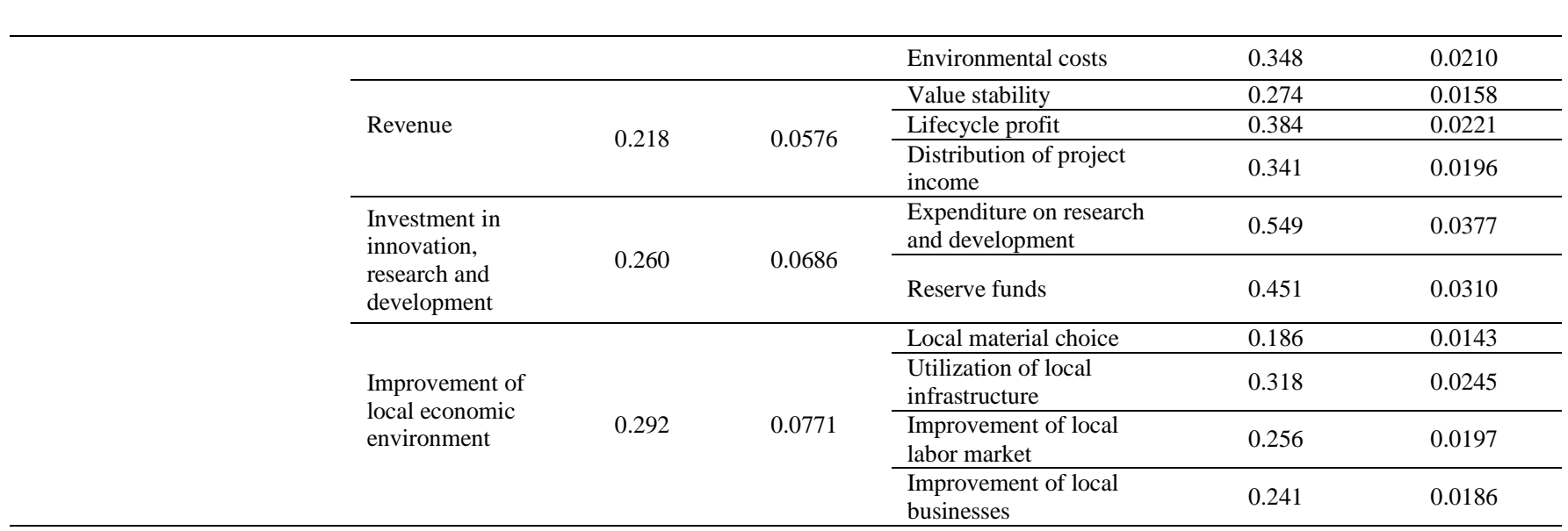



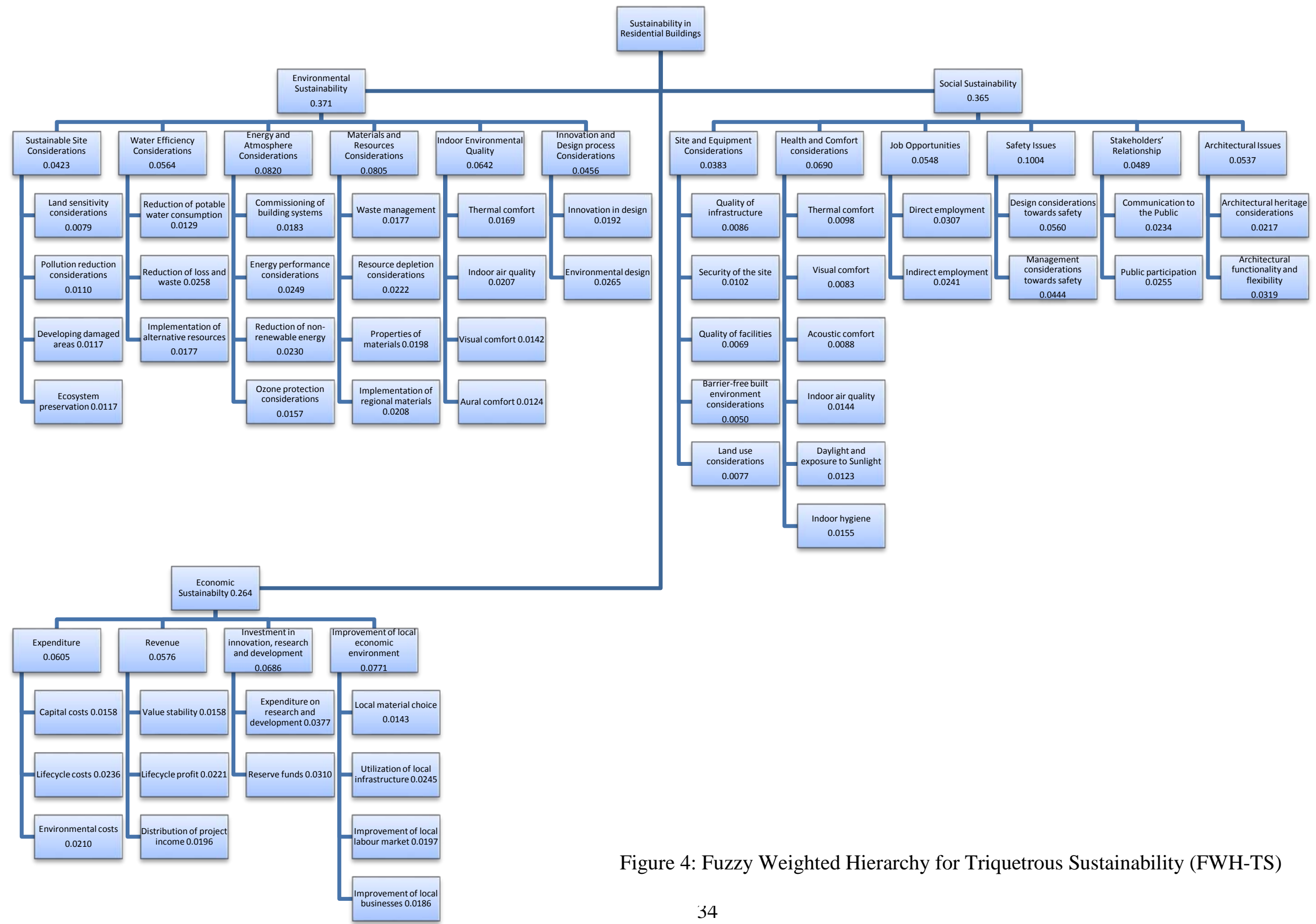
This is a copy of the "Post-print" (i.e., the authors' final draft, post-refereeing). Published as:

Abdul-Rahman, H., Wang, C., Wood, L. C., \& Ebrahimi, M. (in press). Integrating and ranking sustainability criteria for housing. Engineering Sustainability.

The priority weights derived from this study are specifically for residential buildings. The Fuzzy Weighted Hierarchy for Triquetrous Sustainability (FWH-TS) was developed in Figure 4. Practitioners and scholars can employ these priority weights to simplify complicated decision making process in practicing sustainability.

Figure 4 indicates that the weight of environmental sustainability is slightly higher than social sustainability. The weight of economic sustainability in residential buildings is less than either environmental or social sustainability. Table 30 presents the rank of sustainability criteria, according to which the absolute weight of safety issues related to social sustainability is the highest. Site and equipment considerations are less weighted compared to other criteria.

Table 30: Ranking of Priority Weights of Sustainable Criteria

\begin{tabular}{ccc}
\hline rank & Sustainability criterion & Priority weight \\
\hline 1 & Safety Issues (Social criteria) & 0.1004 \\
\hline 2 & Energy and Atmosphere Considerations (Environmental Criteria) & 0.0820 \\
\hline 3 & Materials and Resources Considerations (Environmental criteria) & 0.0805 \\
\hline 4 & Improvement of Local Economic Environment (Economic criteria) & 0.0771 \\
\hline 5 & Health and Comfort Considerations (Social criteria) & 0.0690 \\
\hline 6 & Investment in Innovation, Research and Development (Economic criteria) & 0.0686 \\
\hline 7 & Indoor Environmental Quality (Environmental criteria) & 0.0642 \\
\hline 8 & Expenditure (Economic criteria) & 0.0605 \\
\hline 9 & Revenue (Economic criteria) & 0.0576 \\
\hline 10 & Water Efficiency Considerations (environmental criteria) & 0.0564 \\
\hline 11 & Job Opportunities (Social criteria) & 0.0548 \\
\hline 12 & Architectural Issues (Social criteria) & 0.0537 \\
\hline 13 & Stakeholders' Relationship (Social criteria) & 0.0489 \\
\hline 15 & Innovation and Design process Considerations (Environmental criteria) & 0.0456 \\
\hline 16 & sustainable Site Considerations (Environmental criteria) & 0.0423 \\
\hline
\end{tabular}

The absolute weight of each sub-criterion is presented in Table 31. Design consideration towards safety, which is a social sub-criterion, is the most weighted sub-criterion. The barrier-free built environment considerations under social sub-criterion listed in the bottom.

Table 31: Priority Weights of Sustainable Sub-criteria

\begin{tabular}{ccc}
\hline Rank & Sustainability sub-criterion & Priority weight \\
\hline 1 & Design considerations towards safety (Social sub-criterion) & 0.0560 \\
\hline 2 & Management considerations towards safety (Social sub-criterion) & 0.0444 \\
\hline 3 & Expenditure on research and development (Economic sub-criterion) & 0.0377 \\
\hline 4 & Architectural functionality and flexibility considerations (Social sub-criterion) & 0.0319 \\
\hline 5 & Reserve funds (Economic sub-criterion) & 0.0310 \\
\hline 6 & Direct employment (Social sub-criterion) & 0.0307 \\
\hline 7 & Environmental design (Environmental sub-criterion) & 0.0265 \\
\hline 8 & Reduction of loss and waste (Environmental sub-criterion) & 0.0258 \\
\hline 9 & Public participation (Social sub-criterion) & 0.0255 \\
\hline 10 & Energy performance considerations (Environmental sub-criterion) & 0.0249 \\
\hline 11 & Utilization of local infrastructure (Economic sub-criterion) & 0.0245 \\
\hline
\end{tabular}


This is a copy of the "Post-print" (i.e., the authors' final draft, post-refereeing). Published as:

Abdul-Rahman, H., Wang, C., Wood, L. C., \& Ebrahimi, M. (in press). Integrating and ranking sustainability criteria for housing. Engineering Sustainability.

\begin{tabular}{|c|c|c|}
\hline 12 & Indirect employment (Social sub-criterion) & 0.0241 \\
\hline 13 & Lifecycle costs (Economic sub-criterion) & 0.0236 \\
\hline 14 & Communication to the Public (Social sub-criterion) & 0.0234 \\
\hline 15 & Reduction of non-renewable energy (Environmental sub-criterion) & 0.0230 \\
\hline 16 & Resource depletion considerations (Environmental sub-criterion) & 0.0222 \\
\hline 17 & Lifecycle profit (Economic sub-criterion) & 0.0221 \\
\hline 18 & Architectural heritage considerations (Social sub-criterion) & 0.0217 \\
\hline 19 & Environmental costs (Economic sub-criterion) & 0.0210 \\
\hline 20 & Implementation of regional materials (Environmental sub-criterion) & 0.0208 \\
\hline 21 & Indoor air quality (Environmental sub-criterion) & 0.0207 \\
\hline 22 & Properties of materials (Environmental sub-criterion) & 0.0198 \\
\hline 23 & Improvement of local labor market (Economic sub-criterion) & 0.0197 \\
\hline 24 & Distribution of project income (Economic sub-criterion) & 0.0196 \\
\hline 25 & Innovation in design (Environmental sub-criterion) & 0.0192 \\
\hline 26 & Improvement of local businesses (Economic sub-criterion) & 0.0186 \\
\hline 27 & Commissioning of building systems (Environmental sub-criterion) & 0.0183 \\
\hline 28 & Waste management (Environmental sub-criterion) & 0.0177 \\
\hline 29 & Implementation of alternative resources & 0.0177 \\
\hline 30 & Capital costs (Economic sub-criterion) & 0.0158 \\
\hline 31 & Value stability & 0.0158 \\
\hline 32 & Thermal comfort (Environmental sub-criterion) & 0.0169 \\
\hline 33 & Ozone protection considerations (Environmental sub-criterion) & 0.0157 \\
\hline 34 & Indoor hygiene (Social sub-criterion) & 0.0155 \\
\hline 35 & Indoor air quality (Social sub-criterion) & 0.0144 \\
\hline 36 & Local material choice (Economic sub-criterion) & 0.0143 \\
\hline 37 & Visual comfort (Environmental sub-criterion) & 0.0142 \\
\hline 38 & Reduction of potable water consumption (Environmental sub-criterion) & 0.0129 \\
\hline 39 & Aural comfort (Environmental sub-criterion) & 0.0124 \\
\hline 40 & Daylight and exposure to Sunlight (Social sub-criterion) & 0.0123 \\
\hline 41 & Ecosystem preservation (Environmental sub-criterion) & 0.0117 \\
\hline 42 & Developing damaged areas (Environmental sub-criterion) & 0.0117 \\
\hline 43 & Pollution reduction considerations (Environmental sub-criterion) & 0.0110 \\
\hline 44 & Security of the site (Social sub-criterion) & 0.0102 \\
\hline 45 & Thermal comfort (Social sub-criterion) & 0.0098 \\
\hline 46 & Acoustic comfort (Social sub-criterion) & 0.0088 \\
\hline 47 & Quality of infrastructure (Social sub-criterion) & 0.0086 \\
\hline 48 & Visual comfort (Social sub-criterion) & 0.0083 \\
\hline 49 & Land sensitivity considerations (Environmental sub-criterion) & 0.0079 \\
\hline 50 & Land use considerations (Social sub-criterion) & 0.0077 \\
\hline 51 & Quality of facilities (Social sub-criterion) & 0.0069 \\
\hline 52 & Barrier-free built environment considerations (Social sub-criterion) & 0.0050 \\
\hline
\end{tabular}

\subsection{Results and Discussion}

Our findings reveal that the safety criteria received a high priority which is supported by Ortiz et al. (2009), Kim et al. (2005), and Jensen et al. (2011), from different perspectives. A South African study focused on infrastructure sustainability affirms that the safety indicator is the top sustainability criterion (Ugwu \& Haupt, 2007). Vallance et al. (2011) claim that although the concept of sustainable development at the outset enclosed an apparent social mandate, the social dimension has been overlooked in a sustainable approach for about two decades and the economic aspects of sustainability have also received less attention compared to the environmental aspects of sustainability. The three elements of sustainability are included in most studies which focus on 
sustainable development in the construction industry. However, the environmental criteria have received more attention relative to the other elements (economic and social sustainability). Social facets of sustainable buildings have not been thoroughly examined due to the complexity of the issues (Lützkendorf \& Lorenz, 2005). Jensen et al. (2012) claim that sustainable buildings mainly address energy performance and that not enough attention is accorded to social sustainability. In addition, there is a lack of transference of knowledge from experts to occupants regarding how to utilize low-energy houses more efficiently (Jensen et al., 2012). Therefore, the outputs of our study have successfully filled this gap.

The safety issues were also highlighted by Lee et al. (2011) and Viteikiene and Zavadskas (2007). Further, improvement of local labor market and lifecycle costs were highly weighted in this study, which was supported by Ugwu and Haupt (2007) as key economic criteria. The construction material availability is ranked higher than that in Ugwu and Haupt's (2007) study. The linkage between the sustainable developments along with the construction industry has been apparent, considering the fact that construction is of great economic significance and also includes tough environmental and social effects. Alongside that, the built environment provides the background for the majority of most activities undertaken in today's urbanized environment. The quality of the built environment therefore has a substantial impact on the quality of our existence. Buildings ought to be designed, built, and maintained in a way which fulfils the various requirements of society to provide an appropriate environment, which promotes the development and advancement of individuals and communities. In this research, the implementation of regional materials including the availability of construction materials was ranked as 20 out of 52 sustainability indicators. Energy and atmospheric considerations are ranked as the second most important criterion. This is probably because of the amount of global investment in renewable power generation has been greatly increased relative to investment in fossil fuel energies since 2008 (Oh et al., 2010). The trigger for this change was probably the economic downturn in 2008. Some might argue against a rise of employment as social criteria because it is unclear how relevant this is to residential construction, where most jobs are short-term. However, both Shen et al. (2007) and Shen et al. (2010) fully supported that employment be considered as the level of employment could significantly influence the construction of residences.

The buildings and environment are tightly and symbiotically linked; consequently, as society attempts to provide greater environmental protection, greater concern must be allotted to the 
construction industry. In broad terms, the notion of sustainable development is an endeavor to integrate increasing concerns about pressing environmental issues along with socio-economic issues. Practicing sustainability in the construction industry bears noticeable effects on environmental, economic, and social and design practices (Michael et al., 2009). In addition to the environmental aspects in the building lifecycle, other sustainable dimensions (i.e., the social and economic dimensions) should be accounted for; e.g., the interrelation between the building and community-level issues such as evidenced by social segregation and urban design quality (Lützkendorf \& Lorenz, 2005). Lee (2011) found that 'health' was the most significant indicator for South Korean sustainable high-rise residential buildings. The priority weights developed in our study extended Lee's (2011) findings from South Korea to a broader global market and we demonstrate the relative importance of health and comfort considerations which we find were weighted as the top fifth criterion.

For some years now, the Happy Planet Organization has published the 'Happy Planet Index (HPI)', measuring the trade-off between ecological footprint data and quality-of-life (Gronwald \& Lippelt, 2011); however, HPI did not fit in this study. Due to the lack of country data for some of the variables used in the HPI, it has been necessary to run some missing data estimation procedures. Campus and Porcu's (2010) results show that no country manages to score highly in terms of HPI and economic growth because of countries' incapacity to manage the tensions of maintain high living standards expressed in terms of happy life years and at the same time assure sustainability. Comparing HPI with GDP, no association between the resulting countries' classification has been found, providing evidence that this indicator does not reflect the same reality that GDP illustrates. Tausch (2011) presents some evidence that a wide variety of standard globalization variables have little influence on HPI performance. Big countries with large population resources perform somewhat better, and low military expenditures per GDP are also constraints on HPI performance. Beneficial effects are also closely connected to worker remittances. Efficiency tends to increase and then to decrease with rising development levels.

\subsection{CONCLUSIONS AND RECOMMENDATIONS}

Construction practitioners including contractors, architects, consultants, developers, and other relevant stakeholders are encouraged to use the developed Fuzzy Weighted Hierarchy for Triquetrous Sustainability (FWH-TS) for decision making in residential building projects. The 
priority weight of each criterion and sub-criterion facilitate decision making for practicing sustainability. Though all aforementioned criteria and sub-criteria are non-negligible, to give all sustainability criteria the same level of attention is not only impossible but also impractical. Therefore, the construction practitioners making decisions need to only take into consideration the top $20 \%$ criteria and sub-criteria according to the priority weights to satisfy sustainability objectives. In a way, the developed integrated hierarchy provides a more structured and straightforward framework for stakeholders of the global construction industry. The developed Fuzzy Weighted Hierarchy for Triquetrous Sustainability (FWH-TS) offers the most suitable sustainability criteria and sub-criteria in the three pillars of sustainability, which fills the gap of where, in the case of residential buildings, existing frameworks neglect social and economic sustainability in both theory and practice and do not provide a method to help decision-makers understand relative importance of these factors.

This research has inherent limitations that emerged as we made decisions during the research design process. One limitation was the focus on the use of experts' opinions and judgements to develop the FWH-TS. While we feel that this provides the most comprehensive result, we acknowledge that rankings and prioritizations from the users, or residents, perspectives might provide additional insight and this is an area where the fuzzy AHP process can be extended in future research. The use of some terms may be unclear and while in this case the experts had the opportunity to clarify with the research team what the terms meant, there may have been some misunderstanding. Such misunderstanding of technical terms may be exacerbated when the research is conducted with residents or users. An additional limitation was our focus on residential buildings, which may have significantly different prioritizations than commercial or industrial buildings. This can be addressed with further research that will extend the method to encompass all building types. Further opportunities to apply the method may lead to other derivatives that can be commercialized. Additional work with programmers or software engineers will support the development of software based on FWH-TS in the near future.

\section{REFERENCES:}


Abidin, N.Z. (2009) "Sustainable Construction in Malaysia: Developers' Awareness". World Academy of Science, Engineering and Technology, 29, 801-808.

Amran, A., Zainuddin, Z., Zailani, S.H.M. (2013) "Carbon Trading in Malaysia: Review of Policies and Practices". Sustainable Development, 21(3), 183-192.

Asif, M., Muneer, T., Kelley, R. (2007) "Life cycle assessment: A case study of a dwelling home in Scotland". Building and Environment, 42(3), 1391-1394.

Buys, L., Barnett, K.R., Miller, E., Bailey, C. (2005) "Smart housing and social sustainability: Learning from the residents of Queensland's Research House". Australian Journal of Emerging Technologies and Society, 3(1), 43-57.

Campus, A., Porcu M. (2010) "Reconsidering the well-being: the Happy Planet Index and the issue of missing data". Contributi di Ricerca, CRENoS, C43, E01.

Ceron-Palma, I., Sanyé-Mengual, E., Oliver-Solà, J., Montero, J., Ponce-Caballero, C., Rieradevall, J. (2013) "Towards a green sustainable strategy for social neighbourhoods in Latin America: Case from social housing in Merida, Yucatan, Mexico". Habitat International, 38, 47-56.

Chang, D.Y. (1996) "Applications of the extent analysis method on fuzzy AHP". European Journal of Operational Research, 95(3), 649-655.

Dassen, T., Kunseler, E., Kessenich, L.M. (2013) "The Sustainable City: An Analytical-Deliberative Approach to Assess Policy in the Context of Sustainable Urban Development". Sustainable Development, 21(3), 193-205.

DGNB, German Sustainable Building Certificate. 2009. [online] Available at: http://www.atmosgrad.com/uploads/pdf/DGNBHandbuch_en_44S_20090330a_online.pdf. [Accessed 9 Dec 2014].

Ding GKC. (2005) "Developing a multicriteria approach for the measurement of sustainable performance". Building Research \& Information, 33(1), 3-16.

Dixit, M.K. (2010) "Fernández-Solís JL, Lavy S, Culp CH. (2010) "Identification of parameters for embodied energy measurement: A literature review". Energy and Buildings, 42(8), 1238-1247.

GBI, Residential New Construction (RNC). (2010). [online] Available at: http://www.greenbuildingindex.org/resources.html. [Accessed 12 Dec 2014].

Georgiadou, M.C., Hacking, T., Guthrie, P. (2012) "A conceptual framework for future-proofing the energy performance of buildings". Energy Policy, 47(0), 145-155.

Gronwald, M., Lippelt, J. (2011) "Kurz zum Klima: Zum Wohlder Happy Planet Index". Ifo Schnelldienst, 14(7), 48-49. 
Hill, R.C., Bowen, P.A. (1997) "Sustainable construction: principles and a framework for attainment". Construction Management and Economics, 15(3), 223-239.

Ho, D.C.W., Chau, K.W., Cheung, K.A., Yau, Y., Wong, S.K., Leung, H.F., Wong, W.S. (2008) "A survey of the health and safety conditions of apartment buildings in Hong Kong". Building and Environment, 43(5), 764-775.

Holden, M., Scerri, A. (2013) "More than this: Liveable Melbourne meets liveable Vancouver". Cities 31, 444-453.

Hopwood, B., Mellor, M., O'Brien, G. (2005) "Sustainable development: mapping different approaches". Sustainable development, 13(1), 38-52.

IGBC Green Homes, Rating System Ver 1.0, (2009) [online] Available at: http://www.igbc.in/site/igbc/testigbc.jsp?desc=115708\&event=115679. [Accessed 10 Dec 2014].

Ishizaka, A., Labib, A. (2011) "Review of the main developments in the analytic hierarchy process". Expert Systems with Applications, 38(11), 14336-14345.

Jensen, J.O., Jørgensen, M.S., Elle, M., Lauridsen, E.H. (2012) "Has social sustainability left the building? The recent conceptualization of sustainability in Danish buildings". Sustainability: Science, Practice, \& Policy, 8(1), 94-105.

Kasemir, B. (2003) Public participation in sustainability science: a handbook. Cambridge: Cambridge University Press.

Khalid, R.M., Rahman, S.A., Mokhtar. M. (2013) "Legal Perspective on Development Policies for Sustainability of Water in Malaysia". Sustainable Development, 21(3), 144-151.

Kim, S.S., Yang, I.H., Yeo, M.S., Kim, K.W. (2005) "Development of a housing performance evaluation model for multi-family residential buildings in Korea". Building and Environment, 40(8), 1103-1116.

Lai, A.C.K., Mui, K.W., Wong, L.T., Law, L.Y. (2009) "An evaluation model for indoor environmental quality (IEQ) acceptance in residential buildings". Energy and Buildings, 41(9), 930-936.

Lau, C.J. (2013) "Sustainable urban transport planning and the commuting patterns of poor workers in a historic inner city in Guangzhou, China". Habitat International, 39, 119-127.

Lawanson, O.T., Fadare, S. (2013) "Neighbourhood differentials and environmental health interface in Lagos metropolis, Nigeria". Habitat International, 39, 240-245.

Lee, J., Je, H., Byun, J. (2011) "Well-Being index of super tall residential buildings in Korea". Building and Environment, 46(5), 1184-1194. 
Lee, S.C., Li, W.M., Ao, C.H. (2002) "Investigation of indoor air quality at residential homes in Hong Kong: Case study". Atmospheric Environment, 36(2), 225-237.

LEED, Green Building Rating System For New Construction \& Major Renovations, (2002), [online] Available at: www.usgbc.org/Docs/LEEDdocs/LEED_RS_v2-1.pdf. [Accessed 5 Dec 2014].

Lützkendorf, T., Lorenz, D. (2005) "Sustainable property investment: valuing sustainable buildings through property performance assessment. Building Research \& Information, 33(3), 212-234.

Manan, Z.A., Shiun, L.J., Alwi, S.R.W., Hashim, H., Kannan, K.S., Mokhtar, N., Ismail, A.Z. (2010) "Energy Efficiency Award system in Malaysia for energy sustainability". Renewable and Sustainable Energy Reviews, 14(8), 2279-2289.

Maria, S., Stella, K. (2006) "Present and future of building performance assessment tools". Management of Environmental Quality: An International Journal, 17(5), 570-586.

Michael, P., Matthew, T., Mike, R., Jennifer, L. (2009) "Towards sustainable construction: promotion and best practices". Construction Innovation: Information, Process, Management, 9(2), 201-224.

Mohamed, A.E.H., Sasa, M., Malcolm, W.H. (2002) "Development of a generic framework for collecting whole life cost data for the building industry". Journal of Quality in Maintenance Engineering, 8(2), 144-151.

Mötzl, H., Fellner, M. (2011) Environmental and health related criteria for buildings. Wien: Austrian Institute for Healthy and Ecological Building.

Myers, D. (2005) "A review of construction companies' attitudes to sustainability". Construction Management and Economics, 23(8), 781-785.

Newell, P.J., Seymour, M., Yee, T., Renteria, J., Longcore, T., Wolch, R.J., Shishkovsky, A. (2013) "Green Alley Programs: Planning for a sustainable urban infrastructure?" Cities, 31, 144-155.

Nicol, J.F., Humphreys, M.A. (2002) "Adaptive thermal comfort and sustainable thermal standards for buildings". Energy and Buildings, 34(6), 563-572.

Ochoa, C.E., Aries, M.B.C., van Loenen, E.J., Hensen, J.L.M. (2012) "Considerations on design optimization criteria for windows providing low energy consumption and high visual comfort". Applied Energy, 95, 238-245.

Oh, T.H., Pang, S.Y., Chua, S.C. (2010) "Energy policy and alternative energy in Malaysia: Issues and challenges for sustainable growth". Renewable and Sustainable Energy Reviews, 14(4), 1241-1252.

Ortiz, O., Castells, F., Sonnemann, G. (2009) "Sustainability in the construction industry: A review of recent developments based on LCA". Construction and Building Materials, 23(1), 28-39. 
Pearce, A.R., Hastak, M., Vanegas, J.A. (2012) "A Decision Support System for Construction Materials Selection using Sustainability as a Criterion". SimAUD '12 Proceedings of the 2012 Symposium on Simulation for Architecture and Urban Design. Society for Computer Simulation International San Diego, CA, 10, 1-5.

Pohekar, S., Ramachandran, M. (2004) "Application of multi-criteria decision making to sustainable energy planning: A review". Renewable and Sustainable Energy Reviews, 8(4), 365-381.

Promentilla, M.A.B., Furuichi, T., Ishii, K., Tanikawa, N. (2008) "A fuzzy analytic network process for multi-criteria evaluation of contaminated site remedial countermeasures". Journal of Environmental Management, 88(3), 479-495.

Pulselli, F.M., Ciampalini, F., Tiezzi, E., Zappia, C. (2006) "The index of sustainable economic welfare (ISEW) for a local authority: A case study in Italy". Ecological Economics, 60(1), 271-281.

Quigley, D., Perara, S., Heaney, G. (2007) "Identifying the optimum balance across captital, life-cycle and environmental costs in new build construction projects". In: Boyd, D (Ed) Proceedings 23rd Annual ARCOM Conference, 3-5 September 2007, Belfast, UK, Association of Researchers in Construction Management, pp. 821-830.

Saaty, T.L. (2008) "Decision making with the analytic hierarchy process". International Journal of Services Sciences, 1(1), 83-98.

Sahely, H.R., Kennedy, C.A., Adams, B.J. (2005) "Developing sustainability criteria for urban infrastructure systems". Canadian Journal of Civil Engineering, 32(1), 72-85.

Sev, A. (2009) "How can the construction industry contribute to sustainable development? A conceptual framework". Sustainable Development, 17(3), 161-173.

Sharifi, A., Murayama, A. (2013) "Changes in the traditional urban form and the social sustainability of contemporary cities: A case study of Iranian cities". Habitat International, 38, 126-134.

She, Y.J., Zhu, Y.H., Huang, Q. (2012) "System of Sustainable Construction Based on Project Whole Life Cycle Management". Advanced Materials Research, 403, 2093-2097.

Shen, L.Y., Hao, J.L., Tam, V.W.Y., Yao, H. (2007) "A checklist for assessing sustainability performance of construction projects". Journal of civil engineering and management, 13(4), 273-281.

Shen, L.Y., Tam, V.W.Y., Tam, L., Ji, Y. (2010) "Project feasibility study: the key to successful implementation of sustainable and socially responsible construction management practice". Journal of Cleaner Production, 18(3), 254-259. 
Spence, R., Mulligan, H. (1995) "Sustainable development and the construction industry". Habitat International, 19(3), 279-292.

Tausch, A. (2011) Costa Rica, superstar? some reflections on the global drivers and bottlenecks of the happy planet index, University Library of Munich, Germany in its series MPRA Paper with number 33226.

Tiryaki, F., Ahlatcioglu, B. (2009) "Fuzzy portfolio selection using fuzzy analytic hierarchy process". Information Sciences, 179(1), 53-69.

Ugwu, O.O., Haupt, T.C. (2007) "Key performance indicators and assessment methods for infrastructure sustainability: a South African construction industry perspective". Building and Environment, 42(2), 665-680.

Vallance, S., Perkins, H.C., Dixon, J.E. (2011) "What is social sustainability? A clarification of concepts". Geoforum, 42(3), 342-348.

Viteikiene, M., Zavadskas, E.K. (2007) "Evaluating the sustainability of Vilnius city residential areas". Journal of civil engineering and management, 13(2), 149-155.

Wang, C., Si, Y., Abdul-Rahman, H., \& Wood, L. C. (in press). Noise annoyance and loudness: Acoustic performance of residential buildings in tropics. Building Services Engineering Research and Technology.

Zavrl, M.S., Zarnic, R., Selih, J. (2009) "Multicriterial sustainability assessment of residential buildings". Technological and Economic Development of Economy, 15(4), 612-630.

Zeng, J., An, M., Smith, N.J. (2007) "Application of a fuzzy based decision making methodology to construction project risk assessment". International Journal of Project Management, 25(6), 589-600. Zhang, Z., Wu, X., Yang, X., Zhu, Y. (2006) "BEPAS: a life cycle building environmental performance assessment model". Building and Environment, 41(5), 669-675. 